
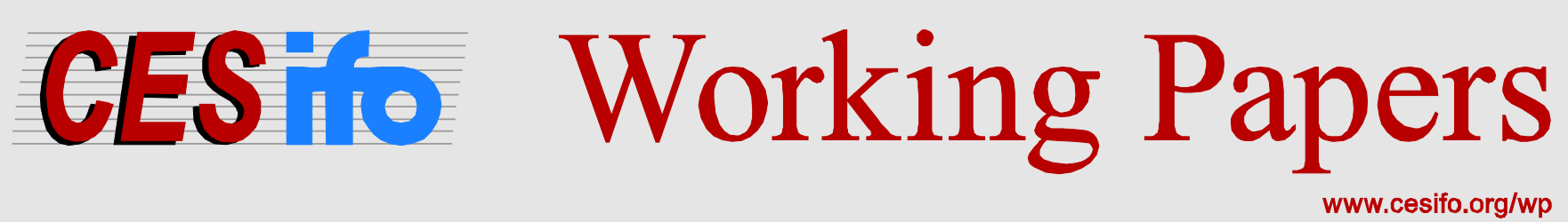

\title{
The Long-Run Evolution of Infrastructure Services
}

\author{
Hugh Goldsmith
}

\section{CESIFO WORKING PAPER NO. 5073 \\ CATEgORY 1: Public FinANCE \\ NOVEMBER 2014}
An electronic version of the paper may be downloaded
- from the SSRN website:
- from the RePEc website:
- from the CESifo website:
WwW.SSRN.com
Www.RePEc.org
www.CESifo-group.org/wp

\section{CESifo}




\title{
The Long-Run Evolution of Infrastructure Services
}

\begin{abstract}
This paper traces the 11,000 year evolution of infrastructure systems during major periods of innovation, expansion and diffusion. Throughout history, the key role of the State is selfevident. Private sector involvement has waxed and waned over millennia, although at times it has been pivotal in bringing innovation, taking risks and driving efficiency. It is argued that positive feedback between early capital market development and investment in infrastructure innovations that lowered system-wide transaction costs has been a critical factor in sustaining growth since 1800. The paper sets out a model of infrastructure innovation cycles, stressing that only an evolutionary, multi-disciplinary, systems approach embracing technology, finance, and institutions can capture such long term, complex dynamics.
\end{abstract}

JEL-Code: H540, B520, O330, N700.

Keywords: infrastructure, evolutionary economics, innovation.

\author{
Hugh Goldsmith \\ Projects Directorate \\ European Investment Bank \\ h.goldsmith@eib.org
}

October 2014

I am grateful to Timo Välilä, participants at the CESifo Venice Summer Institute: "The Economics of Infrastructure Provisioning: The (Changing) Role of the State”, 26-27 July 2013 and to all the researchers involved with the EIB Institute funded research topic "The History of European Infrastructure Finance" for many stimulating discussions on the material in this paper. This paper should not be reported as representing the views of the EIB. The views expressed are those of the author and do not necessarily represent those of the EIB or EIB policy. 


\section{Introduction}

This paper explores innovation in infrastructure services, the roles of different actors and the ways in which this has changed over time. Adequate provision of infrastructure is a sine qua non of economic development. Despite some ambiguous econometric findings, it is generally acknowledged that infrastructure matters for growth, institutions matter for the effectiveness of infrastructure, and that availability of finance is a major constraint to developing infrastructure (Estache 2004; Esfahani and Ramirez 2003). Innovation is about change and change is not necessarily growth. There is an emerging consensus that long run economic change needs to be understood as the co-evolution of technologies and the institutional frameworks within which they are applied (Nelson 2008). The complexity of modern infrastructure as a "system-of-systems" invites a multi-domain, multidisciplinary approach (Hansman et al 2006).

The linkage between infrastructure and economic growth has been the subject of intense theoretical and econometric investigation for over 20 years, both from the perspective of macroeconomic production functions using time series or cross sectional data, and through micro-level studies of individual sectors. Ever since Aschauer (1989) kicked off the debate by claiming large positive growth impacts from public infrastructure investment, the arguments have raged back-andforth, with claim and counter claim about econometric methodologies and the significance, sign and magnitude of results. Good summaries of the evidence and state-of-play at the time are given by Gramlich (1994), Romp and de Hahn (2005), Straub (2008) and Égert et al (2009).

Whilst econometrics struggles to find robust evidence, the need for basic infrastructure is manifest throughout the developing world. In cities hit by natural disasters, infrastructure services are the first priority to get back on-line. Current infrastructure technologies are extremely large, complex, capital intensive network industries, usually managed as regulated monopolies and not renowned for their innovation. Despite innovation now being seen as a critical to the engine of growth, the challenge of changing the way we "do" infrastructure continues to be posed either in a development context or as a need to introduce market forces through privatization, liberalization and public-private partnerships (PPP).

The World Bank has commissioned a number of think pieces on the lessons that history might bring to current debates about infrastructure policy (Eichengreen 1995; Jacobsen and Tarr 1995). The main conclusions are that, although historically private actors have played an important role in infrastructure, the political influence on decisions about infrastructure are never far from the surface. The State needs to play its role, not just through effective regulation, but also through guarantees and other forms of public sector support to attract foreign investment. Whether infrastructure investment decisions have been growth and/or welfare maximizing or simply the result of pork barrel politics is a valid question for many nations (Cadot et al. 2006; Golden and Picci 2008). 
Economic historians have gone more in depth to look at how specific network industries evolved in different countries. Most accounts start with the great nineteenth century innovations of railways, electricity and the telegraph/telephone. The classic works are Foreman-Peck and Millward (1994) and Millward (2005) on the development of water, gas, electricity, transport, and telecoms in UK and Europe from 1830, and Hausman et al (2008) on the role of multinationals in the development of the global electricity industry from the 1880s. The history of infrastructure monographs by Friedlander (1995a, 1995b, 1996, and 2005) gives an excellent overview of all sectors, but she focuses mainly the US and does not specifically look at innovation. A more eclectic approach is taken by the large technical systems (LTS) theory school, following the pioneering work of Hughes (1983) on electricity systems, who stress the critical role played by system builders like Thomas Edison. Even more general socio-technical system theories encompass infrastructure, technology, society, regulation, markets, user practices and cultural meaning (Geels 2004).

There is still no consensus on exactly what should be included in a definition of infrastructure, how to measure it and who should be responsible for building, owning, financing and operating it. Does private or public ownership of infrastructure matter for its long run development? What are the roles of the State and of private companies and markets in driving innovation in infrastructure services? There is a growing interest in exploring historical parallels as a way to inform contemporary policy debates. The invention, deployment and worldwide diffusion of clean water supplies, railways, electricity and the internet are some of the most profound innovations in the history of technology. Does history have anything to tell us about how infrastructure systems evolve and the role of public and private actors in driving change?

This paper seeks to throw some light on these questions by developing a long run narrative of infrastructure service innovations, which is then used to examine how well alternative economic theories match with the stylized facts. In particular, the explanatory power of the evolutionary economic models of Grübler (1990) and Perez (2002) will be considered.

I contend that by looking only at specific sectors, countries or periods, there is a risk that a bigger picture is missed. My thesis is that infrastructure is fundamental to how a society and its economy evolve over time and that this needs to be understood from a multi-disciplinary systems perspective of change, not just economic growth. Although at times it may appear that infrastructure services are simply part of the market economy, such as late $18^{\text {th }}$ and early $19^{\text {th }}$ century Britain and the US, there is also a deeper underlying reality: the power of positive feedback between infrastructure, institutions and financial systems.

The rest of this paper is organized as follows. Section 2 defines the characteristics of infrastructure, its institutions and the key factors influencing planning, delivery and operation that will need to be traced back through time. This is followed by a novel historical sketch of the key developments in several infrastructure systems (urban, water, transport, communications and energy) 
from their origins through to the present day. In each period, I try to identify the key technological, financial and institutional innovations by public and private actors that had a lasting impact on how infrastructure developed. It focuses on what got built, why, how, by whom and what was the long term fate of the system. Very early infrastructure systems are treated in some depth, as this is an area with relatively little academic investigation. Many later examples are taken from the UK, in part because there is good data, but also because many key infrastructure innovations in the $19^{\text {th }}$ century started there.

The following sections identify the relative importance of different actors and technological, institutional and financial factors during each wave of infrastructure system development and diffusion and then sets out a simplified model of the infrastructure innovation cycle over the long run. Next comes a discussion of how well current economic theories fit the stylized historical facts. The paper concludes with a reflection on whether 11,000 years of infrastructure history offer any lessons to today's decision makers.

\section{What is infrastructure and what functions does it serve?}

There is no commonly accepted definition of infrastructure. The Oxford English Dictionary (OED) defines it as: "the basic physical and organizational structures and facilities (e.g. buildings, roads, power supplies) needed for the operation of a society or enterprise: the social and economic infrastructure of a country". Surprisingly, infrastructure is a very new word in English, with a first entry in the OED in 1927. It was rarely used before the 1960s other than in a military context. The Proceedings of the Institution of Civil Engineers, published continuously since 1826, has a first citation for the use of the term "infrastructure" in 1933, in connection with ports and public works in India. Public works was the term used by classic economists from Smith to Marshal to describe roads, bridges, canals, docks, and water supplies.

The essential physical and economic characteristics of infrastructure that we will be looking for as we go back in time are:

- Immobility: fixed in space and needs to be designed for a specific geography;

- Longevity: takes a long time to build and lasts a long time if well maintained;

- Expensive: costs a lot of resources to construct, operate and maintain;

- Public service: provides a basic service that is of value to a community.

A defining characteristic of infrastructure is that it is designed to meet a need in a particular geographical context. Occasionally components can be dismantled and sold, such as when London Bridge was sold to an American oil entrepreneur in 1968 and rebuilt in the Arizona desert, but this the exception. Roads are not traded like used cars. Debates about whether infrastructure provides public, excludable, merit, or demerit goods are largely academic: infrastructure provides public services or services which can become so over time. 
There is no unique way of classifying the different physical infrastructure sectors. Table 1 proposes a classification based on the function served, seeking to avoid overlaps, and reflecting the most common types of contemporary projects presented for financing. In simple terms, individual projects are either buildings with different functions or components of a network. Water, transport, energy and communications are frequently jointly referred to as "economic infrastructure", whilst hospitals and schools are deemed "social infrastructure", although there are good economic arguments to make "Health" and "Education" separate categories.

In practice, all such classification systems need to be treated rather flexibly. Urban infrastructure includes all other categories to some extent, such as public transport and sewerage, although here is restricted to the urban fabric of public buildings and streets that create the urban environment. Some infrastructures can be multi-purpose, such as a dam that is for both water supply, flood defence, hydroelectricity and to control navigation upstream or downstream. A potable water supply can be both a resource input to a production process like brewing beer, but it also plays a vital role in public health and firefighting.

Table 1 Infrastructure service sectors

\begin{tabular}{|l|l|}
\hline SECTOR / SER VICE & TYPICAL PHYSICAL WORKS \\
\hline URBAN & Public buildings; Streets; Street lighting; Leisure facilities \\
\hline SOCIAL & Universities; Schools; Hospitals; Social housing; Prisons \\
\hline WATER & Irrigation canals; Water supply networks; Dams; Drainage; Flood defences \\
\hline TRANSPORT & Roads; Bridges; Tunnels; Ports; Canals; Railways; Tramways; Airports \\
\hline COMMUNICATIONS & Telegraph; Telephone; Wireless; TV; Internet; Broadband \\
\hline ENERGY & Gas; Electricity; Oil; Nuclear; Renewables \\
\hline ENVIRONMENTAL & Wastewater treatment; Waste disposal; Green infrastructure \\
\hline
\end{tabular}

Source: Author's elaboration based on typical investment project categories.

Even the functions of infrastructure can change over time. A London power station is now an art gallery. A railway line has become a cycle way. Today, it may be meaningful to speak of "knowledge infrastructure", of which the internet, education system, and libraries all form part. Some authors include military and even financial infrastructure in their definition. The infrastructure sectors that I will focus on in this essay are the traditional economic infrastructure sectors of transport, water, communication and energy.

A useful clarity brought about by the recent push to get more private sector involvement in infrastructure was the need to define the services that private owners or operators should make 
available to the public. This required a refocus from physical assets to services. Long term private infrastructure contracts need to specify service outputs rather than construction inputs. In other words, it is not the existence of a road that matters, but that all its lanes are open for traffic, that it is well maintained, and that it's safe. Using a framework of services provided rather than focusing on the assets built turns out to be very powerful.

The next step in the argument is to realize that demand for the services infrastructure provides has always been around. As technology advances our expectations of those services has changed, but the need has always been there. Occasionally a new technology comes along which seems to create new markets, such as the mobile phone with internet connection. But equivalent services were already there in 1900 if you sent a letter, installed a telephone and visited the public library. They just weren't as fast, convenient or integrated. Electric light bulbs provide interior lighting services that previously came from gas mantles, lamps, candles, and originally burning torches. A household water supply means we no longer need to walk for hours to the nearest river. So new infrastructure services are always substitutes for how that need was already being met. The critical question is whether the new service is better and/or more affordable.

Finally, what institutions are relevant for infrastructure? Using the metaphor of a game, the term "institution" can be used to describe both the players of the game (e.g. private companies, public administrations, independent regulators, the judiciary), the formal and informal rules of the game (e.g. contracts, regulation, property rights, legal system, acceptance of corruption), and the current state of the game (e.g. ownership structures, effectiveness of legal enforcement). Most authors in the new institutional economics tradition treat institutions and organisation/hierarchies as different. Over the long run, organisations themselves are subject to change. For example, they can change ownership from public to private or they can change their structure from national to multinational. In what follows, I refer to organisations as actors. Institutions and actors can then be considered functionally in terms of different roles and influences they have in the infrastructure project and service delivery cycle: planning, financing, constructing and operating.

\section{A brief history of infrastructure innovations}

What follows is a sketch of some of the key innovations in the history of infrastructure systems. The periodization is deliberately broad brush and events highly selective in order to illustrate the bigger picture. I occasionally add a fast-forward to illustrate how events from the past may be relevant today. The purpose is to identify key innovations and actors that launched the infrastructure services which, with hindsight, evolved to take on global significance. The narrative is not just about technological invention, but also looks at the evolving institutions and financial innovations which allow technological innovations to be deployed on a large scale. Maddison (2007) gives an economic 
narrative and quantitative estimates of key macro-economic data that provide a backcloth to the period starting from the Roman Empire.

Figure 1 shows our journey of infrastructure discovery in the context of rising real global incomes, both the global average and for the leading nation in any period. Over such a long time span, national borders and even the notion of the State itself have evolved. Countries mentioned in the text refer to the modern name of the geographical area, with historically fluid boundaries and related institutions.

A few explanations and disclaimers are necessary before embarking on this journey. Firstly, a relatively long section is dedicated to the ancient world. This is because many of the fundamental ideas about what infrastructure is and what its role is in society were developed by older civilisations. This is the period where the economic history literature is sparsest so I try to fill a gap. Later technological advancement just brought new ways of solving old problems and made solutions cheap enough to be shared by society more widely.

\section{Long Run Global GDP/capita (log-log scale)}

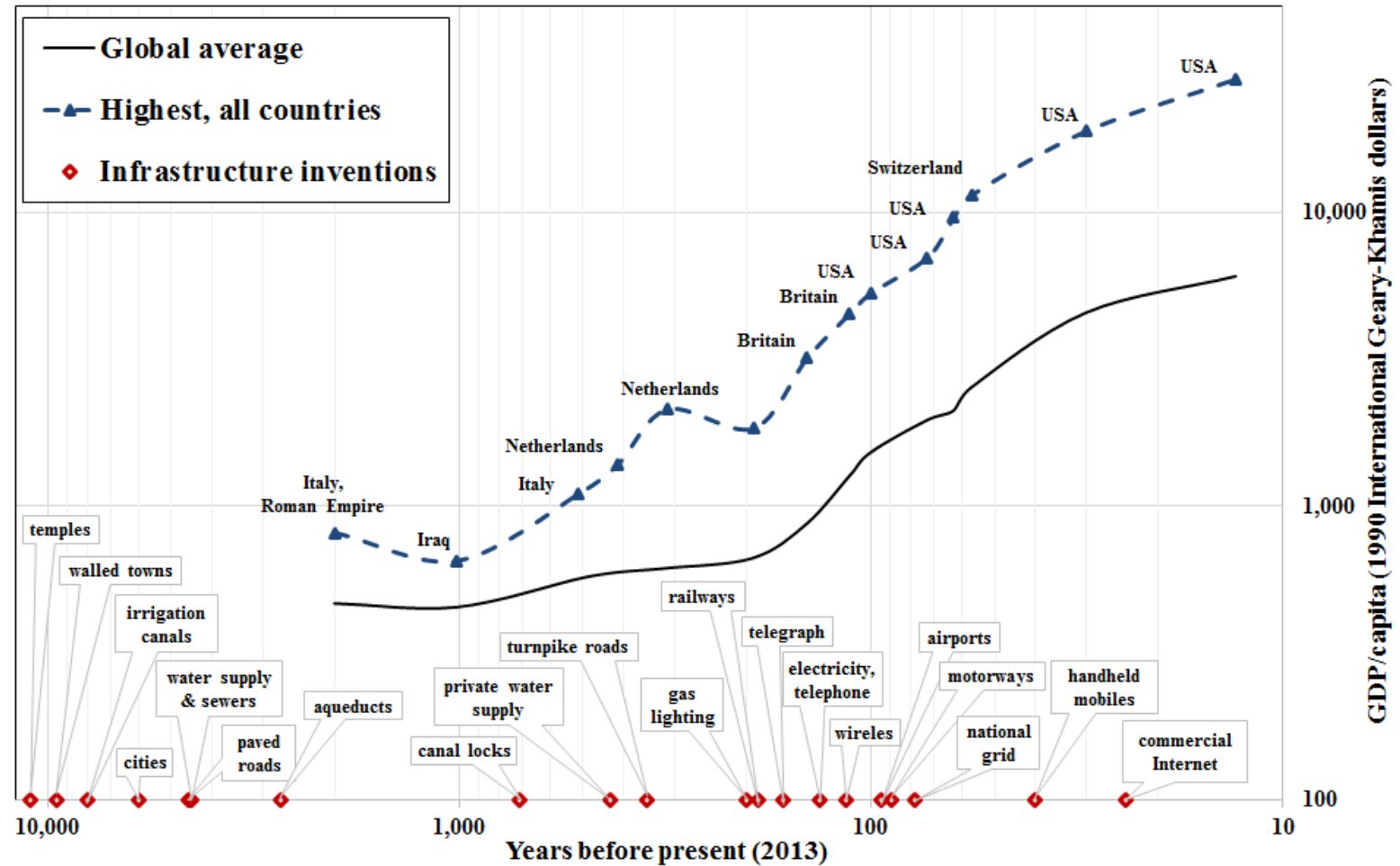

Figure 1. Time line of infrastructure innovations and economic growth

Source: Author's own elaboration for infrastructure invention dates (see text). GDP/capita data from Maddison (2007) - country maximum values exclude small oil states after 1920.

The narrative is primarily focused on the West. This is not to deny the importance of Eastern civilisations for infrastructure innovation. Morris (2010) argues that in periods such as the fourteenth century, China was far more developed in technology and markets than was Europe. Lastly, it is not the purpose here to consider the claims and counter claims of which country or individual was "first" 
with some innovation or invention. Nonetheless, it is worth noting that it is rarely one person or one place that gives birth to a new technology and that, in any case, diffusion of good ideas is usually fast.

\subsection{BCE to 2500BCE: Building civilisations}

On the basis of current archaeological knowledge, the starting point of any infrastructure time trip back to the present must be Göbekli Tepe, a complex of early Neolithic structures on the hilly flanks along the northern rim of the Mesopotamian plain. Göbekli Tepe is the world's first temple (Schmidt, 2000). The earliest structures date to before 9000 BCE, pre-dating Stonehenge in Britain by some 6000 years. The part-buried buildings are circular, $15-25 \mathrm{~m}$ in diameter, with monumental T-shaped limestone pillars set regularly within dry stone walls. Each building contains two central free standing pillars decorated with carved animals and human forms, some of which are up to $6 \mathrm{~m}$ high and weigh 20 tonnes. Up to 500 workers must have worked at the construction site, and the early Neolithic hunter gatherer society clearly generated sufficient surplus to feed them. The group effort and skills needed to conceive, quarry, transport, erect and carve them using Stone Age tools is astonishing. As far as we know now, there was nothing like it before.

So here it is, the first, large scale, permanent structure to serve a community, involving an innovative technology and built to last. The idea of constructing massive, monumental stone buildings as inspirational infrastructures for religious worship spread slowly across the globe over the following 10,000 years, with a great flowering in the golden age of gothic cathedrals and grand mosques. Despite the lack of direct economically productive function, these first social infrastructures bound communities together, became centres of learning/knowledge, and the cities which grew up around them regularly spent huge amounts of resources to rebuild and enlarge them.

Our next stop is the first walled town at Jericho around 7000 BCE and the invention of safe urban living. Jericho had massive defensive walls $3.5 \mathrm{~m}$ high and a taller tower with an internal staircase. Inside the walls, some 70 dwellings occupied $0.025 \mathrm{~km}^{2}$. The walls had to be rebuilt several times, but functioned until around 1500BCE. Inside the protected town, new forms of urban living developed along with domestication of cereals and animals. The idea spread, and the scale of urban infrastructure grew. The need to build city walls to protect cities from the enemy without lasted well into the late Middle Ages.

Figure 2 illustrates the growth in the world's largest cities from ancient times. These cities were usually the capitals of the most advanced State of the day. The need to support the increasing scale of urban living, to connect cities to each other and to bring resources into cities for life support was a major driver of infrastructure growth, both in scale and in the complexity of organizations needed to manage projects and services.

Uruk is situated on the banks of the Euphrates river in modern day Iraq. By the end of the 4th millennium BCE it covered an area of $2.5 \mathrm{~km}^{2}$ within $9 \mathrm{~km}$ of massive city walls of clay bricks, made 
famous by the first surviving work of world literature, the Epic of Gilgamesh. By now, urban living was on a far grander scale, with laid out gardens, streets, residential areas, temples, and a library for the newly invented communication and knowledge storage system using clay tablets: writing. There was a palace for another institutional innovation: the king. Uruk was the first of a succession of autonomous city states being established across Mesopotamia, characterized by new elements of social, economic, and religious complexity.

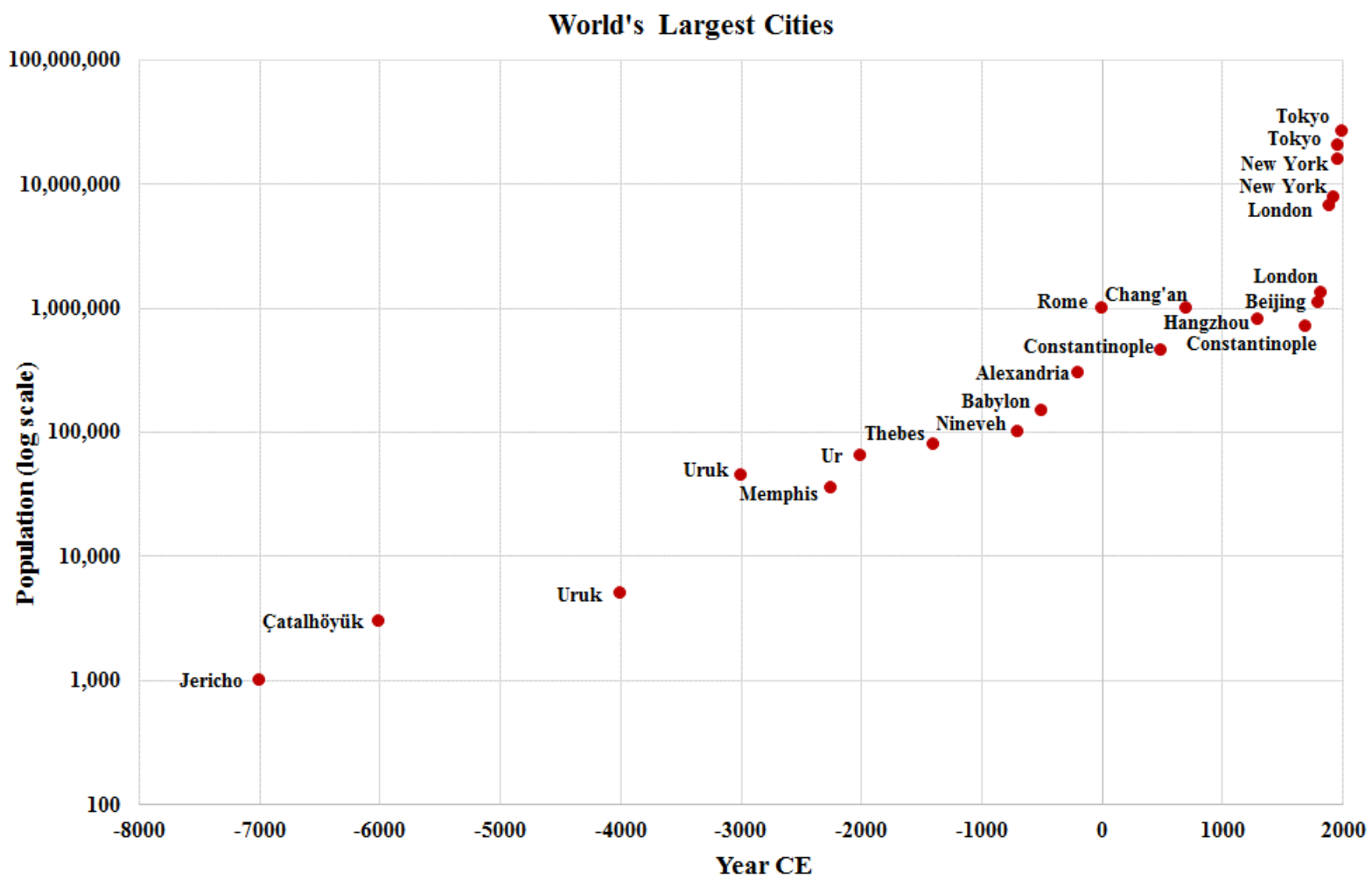

Figure 2. The long run growth of infrastructure's biggest customer

Sources: Author's elaboration based on selected data in Morris (2010) and Chandler (1987) (Chandler's updated data available at The Institute for Research on World-Systems website at http://irows.ucr.edu/research/citemp/citemtoc.htm - accessed November, 27 2013). Population estimates and when they reached "world's largest" status vary between authors.

The other great infrastructure innovation of Mesopotamia was irrigation. Earliest archaeological remains are simple irrigation channels from around 6000BCE (Bagg 2012). By 2100BCE, large scale construction and maintenance of irrigation channels is well documented in cuneiform records showing that it is organized by the State. Although the original ideas of Wittfogel (1957) that public administration and the State arose as a social construct in order to manage complex hydraulic systems are now largely discredited, the fact remains that irrigation can more than double crop yields compared to rain fed agriculture. The resulting rapid population growth and urbanization in an essentially arid environment depended on irrigation systems. Here, the infrastructure is a direct input to economic production and growth is measured in biomass of people, plants and animals.

We start to see the first conflicts over water rights between cities. Mithen (2012) argues that water infrastructure and control of water resources were central to securing and maintaining power in 
the ancient world $\ldots$ and that in water scarce regions the same dynamic continues today. Similar large scale hydraulic technologies started to appear across Mesopotamia, Egypt, India and China, including massive masonry dams to divert rivers and new land reclamation projects combining diversion, irrigation and drainage. Some authors claim that climate change and failure to manage the agricultural production systems sustainably led to the collapse of whole civilizations (Diamond 2005). On the other hand, there are examples of water supply and irrigation systems still in use today that have functioned continuously for over 2500 years, such as those around Lake Van in Turkey (Garbrecht 1980).

\subsection{BCE to 200BCE: The Age of Empires}

As cities vied to dominate each other, professional armies were established and empires rose and fell. A biblical story of Sumerians, Akkadians, Assyrians, Hurrians, and Hittites follows. By the time of the Akkadian Empire of Sargon the Great (2250BCE), it is considered meaningful to talk about a State rather than just a city. The Law was codified for the first time as a formal institutional framework, such as the "eye-for-an-eye" Code of Hamurabi (1790BCE), which covers land tenure, rent, inheritance, contracts, debt, public order, administration of justice, and labor conditions.

Banking and debt were invented around this time, with richer merchant families making grain loans to traders carrying goods between cities. By 500BCE professional bankers had developed such as the Babylonian House of Egibi (521-487 BCE). But there is no evidence of debt finance being used to pay for large scale public infrastructure projects. Infrastructure was directed and built by the State and paid for by taxes, with military supervision of construction.

Forced or slave labour made up the majority of the input into large scale construction projects into modern times. As late as the 1860 s, forced labour from fishing villages was still being used to build the Suez Canal until pressure from investors and international public opinion forced the company to curtail the practice, and import modern steam powered dredgers and excavators from specialist French contractors to complete the project (Bonin 2010).

Labour markets started to develop around infrastructure projects. Adam (2010) describes a recent cuneiform translation of records from a construction project for the city of Ur around 2030BCE that provides evidence on how work was organized and paid for. The project was overseen by a military general and his assistants, but carried out by a mixture of hired laborers and slaves. By this time slavery was well established. Slaves could be inherited, bought and sold, freed, taken as war prisoners or given as payment for debt. However, women, mostly unskilled brick-carriers, made up two thirds of the hired free laborers and were paid in barley, although they received only $60 \%$ of the male wage.

Household water supply and sanitation systems were first developed in this period. Some authors point to the Indus Valley civilization as a "first", with towns like Mohenjo-daro having 
sophisticated water supply and sanitation systems for every house by around 2450BCE (Jansen 1989). Other contenders are the Minoan civilization, with the Queen's bathroom in the Palace at Knossos demonstrating an extremely high degree of knowledge about internal plumbing systems. In any case, piped water supply and wastewater systems were understood well before the Romans.

By 700BCE, the new King Sennacherib of Assyria had accumulated enough wealth to embark on the biggest urban project seen to date to make Nineveh the most spectacular city on earth. He diverted the river, built new temples, gardens, street layouts and constructed the world's first masonry raised aqueduct to bring drinking water into the city from Jerwan, 40km away. The city walls enclosed an urban area of $7.5 \mathrm{~km}^{2}$ and the population swelled to nearly 100,000. As the Assyrian Empire collapsed, Nineveh was sacked and raised to the ground in 625BCE.

There is something of a pattern emerging. Infrastructure is built by the State. Economic activity and trade develops. Then the whole thing is raised to the ground by an enemy State that steals the gold, any useful assets and takes the population into slavery. This evolutionary economic process lasted several thousand years. What also lasted was knowledge about the deeds of great kings and the wonders they built. This knowledge was codified in marble inscriptions and in the texts of Greek and Roman historians. The gist is that good kings built cities, irrigation canals and roads for the benefit of their people, whilst bad ones waged unnecessary wars and built large palaces for themselves.

Between 550 and 450BCE, three generations of Persian kings, Cyrus, Darius and Xerxes, expanded the Achaemenid Empire, to become the largest State up to that time. It had a population of some 50 million and covered an area of 8 million $\mathrm{km}^{2}$. Darius divided up the empire into Governorates and raised huge amounts in taxation, which he then spent on building a new city at Persopolis and undertaking major public works notably in transportation.

Darius built the largest road network seen to date, the backbone of which was the $2700 \mathrm{~km}$ Royal Road from Sardes to Susa. The earliest paved roads date to around 2500BCE in Egypt to connect quarries to the Nile. The Royal Road was not built as a single engineered structure, but joined existing roads into a network. As well as the trade cities along the route, there were additional postal stations every 20 to $40 \mathrm{~km}$ where fresh horses had to be kept. The main purpose of the road network was to ensure swift communication throughout such a vast empire. Trade was secondary and moved at a slower pace. Herodotus states: "there is nothing in the world that travels faster than these Persian couriers", who could carry a message from Sardes to Susa in 7 days. The Royal Road was the fiber optic cable of its day, though traveling at the speed of a horse rather than of light. The communication system relied not just on the existence of the road, but the messengers, postal stations and administrative rules that allowed it all to function. Darius is also credited with completing the first Suez Canal, inscriptions from which were discovered during the construction of the modern version in the $1860 \mathrm{~s}$. 
An important system of water management infrastructure developed by the Achaemenid Empire was the spread of qanats (Goblot, 1979). These are long subterranean galleries dug at an upward slope into rock to intercept a source of underground water. The regular outflow is channeled for irrigation. Such small scale sustainable water sources were dug throughout the Arabian Peninsula and what is now Iran. Over 18,000 have been identified in modern Iran, many still working. According to the Greek historian Polybius, a Royal Decree granted any private individuals/families who dug and maintained a qanat the right to all profits for 5 generations (Lightfoot, 2000). Such works entailed a high risk of tunnel collapse or of not producing a reliable flow of water. Once built, they were operated and maintained for centuries. Sometimes they fell into disrepair or were abandoned as Empires rose and fell, but when calmer times returned they were repaired and brought back into productive use. This is one of the earliest references to private infrastructure development based on a time-limited, risk-sharing contract with the State.

After a succession of wars between Greece and Persia, Alexander the Great conquered the Persian Empire in 330BCE. The Greeks made huge advances in scientific knowledge, law, philosophy and government, but they were not large scale infrastructure builders outside of their own cities, partly because the local geography favored sea based transport.

An exception was water engineering. Koutsoyiannis and Angelakis (2003) document how the ancient Greeks furthered hydraulic engineering in a number of areas, including land drainage and tunnelling. The Greeks established a legal framework for water services in cities. Solon was elected Officer of the Fountains of Athens by public vote in 594BCE. This made him responsible for the operation and maintenance of the city's water system, including enforcement of regulations and ensuring fair distribution of water. At that time, the city had a mixture of public and private wells. He passed a law that owners of private wells should maintain them in good condition to be ready for use in case of war. He also rationalized the system, by decreeing that citizens could only sink a new private well when there was not a public well within a distance of $710 \mathrm{~m}$.

One of the most astonishing ancient documents about infrastructure to come down to us is the contract from 318BCE, carved on a marble stele, between the independent Greek city of Eretria and a foreign contractor called Chairephanes (Knoepfler 2001). The contract details the engineering works planned in order to drain a lake at Ptechai. It has all the features of a modern project finance contract in terms of risk allocation, including:

- the contractor to meet all expenses plus pay a lump sum of 30 talents to the City;

- the contractor is granted exclusive right to cultivate and retain the products of the reclaimed land for 10 years;

- an exemption from local taxes and certain laws;

- a 4 year construction schedule, which could be extended in case of war, but an obligation on Chairephanes' heirs/collaborators to complete the works in case of his death;

- extreme sanctions against anyone attempting to cancel the contract;

- the contract was "signed" by 230 citizens with six named Eretria-citizens as guarantors. 
For transparency, the marble contract was to be on public display and a copy deposited at Delphi. Unfortunately, other than the inscription, the exact location of the lake and whether the contract was ever executed are unknown. Concession contracts of a similar form were used by the Romans for works related to public services and continued to form the legal basis for a 2000 year history of public-private partnerships in France (Bezançon 2004).

By 200BCE, as Rome was starting to build the greatest Empire seen to date, the technology and institutions for managing water, transportation, communications and urban infrastructure services were well established.

\subsection{BCE to 500CE: What the Romans did for us}

The Romans took the idea of infrastructure as a driver of development to a whole new level. They militarily conquered and culturally subsumed much of the known world, and in the process they shamelessly borrowed technology and ideas from the Greeks, Persians, Carthaginians and Etruscans. They also did everything on a grander scale and with a greater purpose. For lesser nobles from conquered tribes, they offered the seduction of civilized life and access to goods from global markets. The roads, aqueducts, sewer systems, civic spaces and public baths that came in the wake of the legionnaires were as much what built the empire as the laws, language and common currency. In civil engineering, the invention of concrete using slaked lime combined with volcanic ash known as pozzolana allowed them to create durable water proof structures, many still functional today.

From the end of the second Carthaginian war in 201BCE, Rome embarked on a period of expansionist Empire building that reached its largest geographical extent in $117 \mathrm{CE}$, at which point the Emperor Trajan ruled over an area of 6.5 million $\mathrm{km}^{2}$ and a population in excess of 70 million. Temin (2006) claims that at this pinnacle of economic and social achievement, Rome was a market economy built on a long period of stable government, with well-functioning market institutions, including financial intermediation. It also possessed transport and urban infrastructure that would not be matched again in Europe until after 1800.

In terms of infrastructure services, Rome was the largest and most sophisticated city in the world. Even the poor living in the great cities of the Roman Empire were rich in the public goods available to them. The urban poor, often freed slaves, lived in great poverty in the slums, but "had the great public baths and public squares and parks and forums, in which he reckoned to spend far more time out of his house than is normal in the modern north" (Griffin 1986, 9).

The Romans left a recipe book for building the physical infrastructure of civilized life. Vitruvius' (c. 70 - 10 BCE) ten books on architecture set out the public and private works required to construct a city: selecting the site, building its walls, the layout of streets and public buildings, housing, materials, temples, forum, basilica, treasury, prison, senate, theatre, public baths, palaestra, harbours, breakwaters, shipyards, aqueducts, wells, cisterns, and finally machinery (Vitruvius Pollio, 
1914). This is literally a procedures manual of how to construct civilized life based on the six Greek principles of Order, Arrangement, Eurythmy, Symmetry, Propriety, and Economy. Vitruvius' opus is dedicated to the Emperor Caesar whom he lauds as giving "attention not only to the welfare of society in general and to the establishment of public order, but also to the providing of public buildings intended for utilitarian purposes".

Even in Vitruvius' day, good practices from the past were being forgotten. Vitruvius records that the Romans completely lost the disciplines of the Greeks in controlling the cost of public works. He cites a law in the Greek City of Ephesus which required architects, when entrusted with a public works project, to lodge a cost estimate with a magistrate. The architect's property was held as security until the work was finished. On completion, if the final cost did not exceed the estimate, he was celebrated with decrees and honours. When the cost exceeded the estimate by no more than a quarter of the original estimate, it was defrayed by the public purse and no punishment inflicted. But when the cost overrun was more than $25 \%$, the architect was required to pay the excess out of his own pocket. He bemoans: "God that such a law existed among the Roman people, not only in respect of their public, but also of their private buildings, for then the unskillful could not commit their depredations with impunity".

Knowing roughly how much a big infrastructure project will cost is fundamental to making a decision about whether to go ahead. If the cost turns out to be double the original estimate, then the economic rationale for doing the project in the first place may be weak or non-existent. Flyvbjerg et al (2003) show that large infrastructure cost overruns caused by "optimism bias" are still a curse today.

The Roman Empire developed the most sophisticated large scale transportation and communication system the world had seen. The paved road network at its peak was slightly in excess of $80,000 \mathrm{~km}$ with a further $320,000 \mathrm{~km}$ of unpaved minor roads that reached to the furthest corners of the Empire. Road sizes and the legal status of public rights of way were already standardized by 450BCE in the Law of the Twelve Tables. The right of the population to use public roads was protected by law. Paved roads were constructed on the principle of economy to be as straight as possible and built to last according to standards that minimized long term maintenance needs.

Roads were subjected to an evolving system of governance and financing. Although the State financed road construction through taxes, longer term maintenance was devolved. Road building was part of empire building and logically was organized under the military responsibility of a Consul outside the city walls. Each municipality was responsible for the roads within its boundaries. Although the majority of funding continued to come from taxes, some Consuls such as Julius Caesar spent considerable amounts from their own resources to maintain roads under their personal responsibility. Gifts to fund infrastructure such as bridges or buildings by wealthy citizens were 
common, although of minor overall significance. De Luca and Lorenzini (2013) explain how Roman systems of infrastructure finance lasted well into the mediaeval period.

A major reform took place under Augustus, who first made himself supreme head of the Empire's road network and then created a commission of Senators, the Supervisors for Roads, with personal responsibility for their upkeep (Eck 2003). In practice, the Supervisors worked with local officials and contractors to organize regular repairs. Although travel on roads was free, charging tolls at bridges and town gates to vehicles transporting goods was a standard way to raise local taxes, but these were not directly applied to road maintenance.

Augustus also reorganized the legal responsibilities for water supplies and sewerage. We know from Frontinus, who took over as Commissioner for the Aqueducts of Rome in 95CE that the system was in a poor state of maintenance and repair, with a lot of fraud and many illegal connections. Citizens had the right to collect free water from public fountains distributed evenly throughout the city. Private supply connections to an individual villa could only be authorized by the Emperor and had to be paid in proportion to use as estimated by the size of pipe. Water rights were personal and did not automatically pass to the heirs or purchasers of a property.

Frontinus took over a public company dedicated to the operation and maintenance of Rome's water supply system with 700 workers, mainly slaves. Its costs were covered by the Imperial budget, against which was offset some income from payment for water rights. In short, there was a complex system in place for operation and maintenance of services with a small income from private connections, but the service was predominantly public and paid from general taxation.

Finally, there was a good communications network throughout the Empire using the roads and ports. The Cursus publicus, founded by Augustus, carried official mail by relay throughout the Roman road system. This replaced a dual system of public mail used by officials and private citizens alike and a private postal system for wealthy citizens carried by tabellarii, who were slaves and free citizens who would carry private messages or letters for a price. At Vindolanda fort on Hadrian's Wall in Britain at the outer fringes of the Roman Empire, archaeologists have found letters from legionnaires to their families back home requesting warm clothing to cope with the harsh weather.

Whilst it is important not to slip into anachronism, it is equally important not to underestimate how similar some aspects of everyday life, including commerce, were in the ancient world. Toutain (1930) explains the complexity and evolution of economic activity through antiquity until the end of the Roman Empire in the West. He describes the impressive scale of Roman trade and its dependence on transport and other forms of infrastructure. Commercial traffic had to pay a number of duties and taxes, collectively referred to as "portorium", at the frontier of a province or state for the benefit of the state, on entering or leaving a town for the benefit of that town, and a toll for passing certain points such as bridges (Toutain 1930, 312). Pliny reports that goods from India, such as highly valued 
pepper, increased in price a hundred fold by the time they reached their destination. Thus, whilst the State provided the transport system, it also derived a large part of its revenues from taxes on the trade it enabled.

Although urbanization increased significantly during the Roman Empire, the society remained predominantly rural with the majority employed in agriculture to feed themselves, the landowners and the cities. Maddison (2007) estimates that about $14 \%$ of the population in peninsular Italy lived in urban areas by $150 \mathrm{CE}$, which was similar to the degree of urbanization in 1800 . The main benefits from infrastructure were therefore only experienced by a minority of the population. Better roads and communication directly benefited the State, including the army, and an elite of private merchants. With the exception of Britain and the Netherlands, urbanization remained below $20 \%$ until after the 1850s. The need for infrastructure was in part driven by the scale of cities, Empires and markets, which in turn was defined by the scale of infrastructure provided.

\subsection{CE to 1500CE: Castles, cathedrals and the rebirth of cities}

In the $5^{\text {th }}$ century, the Roman Empire in the West collapsed. Rome was sacked by Alaric the Goth. Britain was abandoned in 410CE. Roman infrastructure continued to function, but in a state of slow deterioration. Popes funded the rebuilding of Rome's aqueducts whenever the system looked in real danger of collapse. Mirroring the priorities of those who controlled resources at the time, the main type of new infrastructures built were castles and cathedrals.

The following centuries were extremely turbulent in Europe, with invasions and military conflicts as the Roman Empire fragmented, was reunited under Charlemagne and then fragmented again. Feudalism and serfdom became the dominant economic production system. Compared to the past, it is hard to point to any great achievements in infrastructure before 1000CE. In 793CE, Charlemagne built a new canal, the Fossa Carolina, to connect the Rhine with the Danube basins, but it was only $3 \mathrm{~km}$ long. During this period, China was carrying out gigantic engineering works using forced labour, including the completion of the Chinese Empire's new superhighway: the $1700 \mathrm{~km}$ Grand Canal. In the Muslim world, Baghdad grew to become the largest city on earth and a center of multi-cultural learning.

In Europe, a shift started after 1000CE, with old and new cities in Italy and Flanders emerging as powerful commercial centers. Venice established a trading monopoly with the east and used the resulting wealth to build an extraordinary city in the middle of a lagoon. This rebirth of commerce was closely bound up with continued trade links with Byzantium (Pirenne 1956). The Roman Empire in the East continued until the fall of Constantinople in 1453, which remained one of the largest cities in the world.

Land reclamation projects using dyke and drain infrastructure started to create new wealth and new landowners, with the first polder recorded in Flanders in 1150 (Pirenne 1956, 81). A new 
merchant class grew and established itself as new town "burghers" around fortified strongholds. The new cities were given powers to make their own laws and tax local markets. Any serf who lived within city walls for a year and a day could earn their freedom. Flanders merchants introduced new textile manufacturing and dying techniques, such that by the twelfth century they came to dominate the northern European cloth market. Toll collection (teloneum) on roads and canals grew again as an important source of taxation. This new found economic surplus found expression in the great cathedrals built across Europe from the twelfth to sixteenth centuries and in the public and private infrastructure of towns like Ghent and Bruges.

In the Middle Ages, water remained the responsibility of city councils (Magnusson 2003). Cities improved water supplies by building "conduits", funded by taxes and frequently developed in collaboration with local monasteries or with royal support. The church maintained the old Roman knowledge of hydraulic engineering. One of the earliest surviving maps of a piped water distribution system comes from Canterbury Cathedral in UK. Construction of London's Great Conduit in 1237 relied on a grant of land and springs from the King and contributions from merchants in cities such as Amiens who received trading privileges in return. In 1340, Sienna funded new drinking water fountains from a tax on its dependent territories. In Paris, Dublin and Southampton the town council collaborated with the local monks to develop and maintain water supply systems.

\subsection{0 to 1800: Private water, roads and canals}

From 1500 onwards, private rather than public investment started to play a significant role in infrastructure investment with Britain in the lead. This coincided with the age of European voyages of exploration, the start of a scientific revolution following the discoveries of Copernicus, and formation of the earliest joint shareholder corporations. The various companies trading with the East Indies and beyond were established with private capital, but often with the monarch heavily involved.

\subsubsection{Water}

Water supply led the first in a succession of institutional innovations in infrastructure. The private London Bridge Waterworks Company opened in 1582. Its success relied on the application of new technology, a force pump operated by a waterwheel in an arch of old London Bridge, the legal protection of Letters Patent signed by the Queen, and a 500 year lease contract with the Corporation of London for a bridge arch (Goldsmith, forthcoming).

By far the most important private company was New River Company, incorporated in 1619. It required an enormous capital investment for the time to build a $60 \mathrm{~km}$ new river (actually a canal) conveying an additional fresh water supply to the city and then distribute it via wooden pipes. The technology was barely Roman. The real challenge was the scale of private financing, which was raised through 36 "Adventurers" shares. In reality, the project was driven by the private wealth and vision of a single man, a rich goldsmith called Hugh Middleton. His brother was the mayor of the 
City. Certain innovative clauses in the Royal Charter helped to overcome difficulties in expropriating the land for the project as well as establishing a legal monopoly over water supply to the city. When construction costs started to spiral over budget, the King injected an additional $50 \%$ of new capital to complete the project. The early years were financially challenging, but after a few decades it had paid back original investors many times over. It went on to be described as "the most remunerative and successful of all the trading corporations of the world" (Ward 2003, 228). London's water services were consolidated and then transferred to municipal ownership in 1904 and later reprivatized in 1989.

\subsubsection{Bridges}

Charging tolls to cross bridges goes back to Roman times. The earliest bridge in London was Old London Bridge, which took over 33 years to build, through the reigns of $3 \mathrm{kings}$, before completion in 1209 under King John. To finish it, he had to borrow heavily from City Merchants and in return granted land to fund its upkeep. As well as tolls, it was decided to develop property on the bridge for extra income. The bridge became the tidal limit of the River Thames as its narrow arches blocked the flow. The buildings on the bridge had to be substantially rebuilt after the Great Fire in 1666, but it was not until 1754 that an Act was passed to remove all the buildings. Since a Royal Charter in 1282, Old London Bridge was operated and maintained by the Bridge House Estates Trust, under the control of the Corporation of London. Owning land in the capital city, it became so wealthy from property and other investments that it was able to remove all tolls on its bridges. Today the Trust maintains 5 central London bridges at no charge to the public purse. If one of them collapsed, it would be rebuilt by the Trust.

Iron Bridge, over the River Severn in Shropshire, England was the world's first large span structure made entirely of cast iron. The bridge was promoted by its builder Abraham Darby, who owned the local iron foundry making the cast iron components. It opened in 1781 after 2 years construction. It was pure project finance, with construction funded from the sale of 60 shares at $£ 50$ each, to be paid back entirely from toll revenues. It was a financial success. The tolls were set by an Act of Parliament of 1776 and thereafter couldn't be increased other than by amending legislation, which is why pedestrians were charged a halfpenny to cross for nearly 200 years until the toll was removed in 1950. Similar project finance techniques for bridges were used in France before and after the revolution in 1789. By 1843, there were 5 bridge companies listed on the London Stock Exchange. From the 1850s onwards, bridge project finance based on tolls disappeared in the UK as road and bridge construction became publicly funded. It was reinvented in the 1960s for the new Severn Bridge and used for later estuary crossings.

\subsubsection{Turnpikes}

The next revolution was in the British roads system. Turnpikes were primarily a financial and institutional innovation that created a financing vehicle for road maintenance and improvements. 
They predated the industrial revolution. The first Turnpike Act was passed in 1663 to turnpike $48 \mathrm{~km}$ of the Great North Road in Huntingdonshire, on the country's main north-south transport link. It was approved following a petition by local parishes claiming that they could no longer adequately maintain the road with local corvée statute labour, because traffic was so heavy.

The next Turnpike Trust Act was not until 1695, after which there were several a year. Up to 1706, turnpike trusts were always controlled by local magistrates. In 1707, the first Turnpike Act with trustees who were not local Justices of the Peace was approved and this became the standard model. This institutional adaptation had important consequences as it allowed local landowners, farmers and businesses who would directly benefit from road improvements to promote a new Trust.

Turnpike Acts authorised a not-for-profit Trust to levy tolls on road users and to use that income to repair and improve the road. Legal arguments prevented the Kings Highway becoming a for-profit private company and the Trust was a convenient solution to avoid a burden on general taxation. The 'turnpike' was the gate which blocked the road until the toll was paid. The Trustees could purchase property to widen/divert existing roads and were authorized to borrow against future toll revenues.

The turnpike road network grew organically, radiating out from the main cities, following the directions of heaviest traffic and trade (Pawson 1977). By 1750, virtually all of the main roads from London were turnpiked. The peak for new turnpikes occurred in a so-called "turnpike mania" between 1752 and 1772, when 413 new trusts were created. By the time the last Act was passed in 1836, there had been almost 1000 Acts for new turnpike trusts in England and Wales, and turnpikes controlled about a fifth of the national road network.

Many Trusts were well run, but financial mismanagement and fraud were not uncommon (Albert 2007). A survey in 1824 found that the average ratio of outstanding debt to annual income before expenditure was 4.5 , but for some trusts it was above 20 and clearly unsustainable. Most turnpike trusts were wound up under General Acts of Parliament between 1873 and 1878. By the Local Government Act of 1888, the maintenance of main roads went full cycle by being entirely passed back to County Councils. Road building and maintenance was financed out of local government taxation, and then from 1919 by an annual Road Fund Tax on vehicles, which was later subsumed into the Government's general tax income. Once roads were free, the State found it very difficult to reintroduce user charges, in contrast to the concession finance model used to fund motorways in France and Italy. A classic example of institutional path dependency.

Ironically, the first important technological innovation in roads for 2000 years came almost at the end of the turnpike era. In 1819, the general surveyor for the turnpike trusts in Bristol, John McAdam, published a new method for "the Scientific Repair and Preservation of Public Roads". His techniques, not just of using graded stones for construction, but also his overall approach to the 
organisation and professionalization of road maintenance, became standard practice throughout the world. A century later, when asphalt (a bi-product of the oil industry) became widely available, tarmacadam road surfacing created another technological revolution. But in the UK, road upgrading using the new technology was carried out by local authorities. Private companies made money from efficient contracting and owning patents on the surfacing technology.

\subsubsection{Canals}

The last private transport infrastructure revolution of this era was the construction of a private canal network across the industrial heartlands of Britain. Acts to improve navigations on the Rivers Thames and the Lea date back to the sixteenth century. The key technological invention that made an inland canal network possible was the invention of the pound lock to allow boats to go up a relatively steep land gradient in steps using a chamber between two lock gates. Reputedly invented by a Chinese engineer on the Grand Canal in the tenth century, it was first used in Europe by the Dutch at Vreeswijk in 1373. The system was further refined technically with the addition of mitre gates, probably designed by Leonardo da Vinci, for the canals built in 1458 to transport the marble for building Milan Cathedral. The first use of a pound lock in Britain was on the Exeter canal in 1563.

It was not until the privately funded Bridgewater Canal opened in 1761 and effectively halved the cost of transporting coal to Manchester that private finance and business became interested in canals. Like the New River for London water supply and the Canal du Midi in France, this was a large scale infrastructure engineering project funded from the personal wealth of an individual, in this case the 3rd Duke of Bridgewater. The commoner engineer on the project, James Brindley, developed a number of techniques to overcome construction difficulties, including linings made from puddled clay and an aqueduct over the river Irwell worthy of the Romans. Brindley formed an alliance with influential early industrialists, including Josiah Wedgewood the pottery manufacturer, and developed a plan for a network of canals linking the great rivers of England: the Mersey, Trent, Severn and Thames in a "Grand Cross" (Corble 2011). Brindley went on to build over 580km of canals himself. Independent private canal companies financed by local landowners, merchants and industrialists built the network piecemeal in a "canal mania" frenzy of construction between 1793 and 1820. The network length grew to over $6400 \mathrm{~km}$ and joined all corners of the country. To keep costs down, it was built to a "narrow" gauge, which ended up limiting its future capacity for expansion to take larger barges, unlike the larger gauge network constructed later in mainland Europe.

The invention of railways spelled financial disaster for Britain's canals and most turnpike trusts. Although a few trusts managed to increase revenue by acting as feeder roads for railways, most were in direct competition. 


\subsubsection{Ports}

A lesser researched topic is the substantial investment that Britain put into her ports from 1600 onwards. This was primarily funded by the State, since ports also had a military purpose due to the strategic importance of Britain's navy. However, docks and harbours were granted powers to raise loans against their harbour fees. As commercial interests in shipping grew rapidly in the late $18^{\text {th }}$ century, some commercial ports and harbours raised additional private funding via listings on the London Stock Exchange.

\subsection{0 to 1900: Pipes, rails and wires}

The $19^{\text {th }}$ century saw the most dramatic changes in infrastructure since the Roman Empire. The new boom was fuelled by private capital in the heyday of laissez-faire, but ultimately driven by changes in society, rapid urbanization and expanding markets as railways shrank the world. For intra-urban infrastructure, such as gas lighting, water supply and trams, municipalities were the critical actors either developing services themselves or awarding concessions to private companies. In the latter half of the $19^{\text {th }}$ century, a trend of municipalisation saw many private municipal services being taken back into public ownership, sometimes linked to the municipal socialist movement, but other times simply to take over a highly profitable activity.

For inter-urban infrastructure, such as railways and telegraphs, national Governments had the dominant role in granting concession rights to private promoters, who needed to know how to play the political game in order to get their projects approved. Over time, many services which started as local were pushed by economies of scale towards becoming an integrated national service.

\subsubsection{Gas}

The first in a century of new infrastructure innovations was piped gas for street and domestic lighting. After several technical and commercial false starts, including litigation over rival patent claims and Parliamentary opposition, the London and Westminster Chartered Gas-Light and Coke Company became the world's first gas company in 1810. It started life selling services to private clients, notably mills in the rapidly industrializing north of England, but then switched its business model to selling street lighting to cities. The company's chief engineer and founder, Samuel Clegg, invented the first practical gas meter and patented various technical improvements to coal gas manufacture. Gas distribution used cast iron pipe technology already in use for water supply. Britain was abundant in coal, the raw material needed to manufacture the gas.

The requirement to light city streets can be traced back to 1417, when the Mayor of London ordered householders to hang out lanterns on winter evenings. Paris followed suit in 1524. By 1700, the residents of most cities were required to hang out a lamp every night as soon as it got dark. So the demand for the services that gas lighting could provide were already well established. 
When applied at a commercial scale, gas lighting halved the cost and quadrupled the light output compared to candles. In the US, the first gas lighting opened in Baltimore in 1816. Paris adopted gas street lighting in 1820 using a rival French technology developed by Lebon. Brussels became the first city to be entirely lit by gas in 1825. Gas lighting companies rapidly spread throughout the then developed world as a symbol of progress. The reported reductions in crime rates made street lighting a "must have" for the modern mayor.

To be economic, gas lighting was limited to larger cities with relatively dense distribution networks. Once the mains were in place to light the streets, normally in the wealthier parts of town, additional connections to private premises could be hooked up quite cheaply. From the start, companies and households paid for use rather than just for the connection as was the case for water. Internal fittings to take gas mantles into each room remained a significant private expense that only wealthier households could afford. Cities paid for street lighting based on metered consumption using funds raised from general taxation. Private individuals paid on the basis of consumption. Factories were major early adopters of gas lighting as the new technology lowered costs and improved working conditions. Gas companies often applied lower rates to the municipality to avoid political difficulties and would charge higher tariffs to households and businesses.

Millward (2005) describes how different patterns of private or municipally owned gas companies became the dominant model for expanding services in different countries. In Germany and Scandinavia, the tradition was more for municipal ownership. Once initial investment costs were depreciated, services were invariably net cash generating "cash cows". This provided a useful form of additional income to keep municipal taxes low. In the US, private gas companies became highly profitable. Friedlander (1996) reports that over $70 \%$ of revenues were available for dividends. The extremely high profitability of gas lighting was one of the factors which attracted JP Morgan to invest in a competitor technology when he backed Edison's research into electric lighting. Returns from the London Stock Exchange confirm the high profitability of most gas companies by 1882 .

Gas lighting was eventually substituted by cheaper and more reliable electricity. The gas companies had huge sunk costs, but perfectly viable networks to exploit. After WWI, they increasingly turned their efforts to innovation to develop new markets, first for cooking and then for heating. The industry went through some natural consolidation as larger private companies took over adjoining smaller ones, but the service remained a patchwork of public and private interests. In 1948, the Government nationalized the UK gas industry by merging the 1,062 private and municipal owned gas companies into 12 area gas boards. These were further consolidated in 1972 into a single public company, British Gas, which was privatized again in 1986. 


\subsubsection{Railways}

The next infrastructure revolution changed everything. The Stockton \& Darlington Railway was the pioneer in 1825 , but the railway age really began in 1830 with the success for passengers as well as freight of the Liverpool \& Manchester Railway Company. The story of the engineers, promoters, contractors and financiers that turned a local project into a global industry is well documented.

Railways heralded a transport revolution with far reaching ramifications for communications, finance and corporate organisation. In Britain, railway investments were entirely privately financed. The 2 separate British "railway mania" financial bubbles in railway shares in the 1830s and 1840s destroyed many small investors' savings. The second of these has been called the "greatest bubble in history" (Campbell and Turner, 2010). As with canals, early railway investors represented local interests. By 1844, as the benefits of industrialisation spread wealth more widely, whole new classes of investors were supplying capital for railways (Reed 1975). The battle to establish technical standards was won by Stephenson with the "standard gauge". Network consolidation was achieved through acquisition of different lines by private financial investors such as George Hudson. Starting with the 1844 Railways Act, Government regulations were introduced on pricing, timetabling and coordination to compensate for market failures.

Within 20 years, the railway network length in Britain grew from zero to 6,500 km. But the real story was the growth of railways around the world to $38,152 \mathrm{~km}$ by 1850 , accelerating to 765,222 $\mathrm{km}$ by 1900 . The largest network in the world was the US, which literally built its nation along with the railways. Railway infrastructure went global in less than 70 years. Even Africa had 16,319 km of railways by 1900 , although essentially for exporting natural resources from colonies. Britain was also the main source of global investment finance, especially after 1870 when foreign investments started to offer far higher returns than domestic stocks.

Figure 3 shows the relative rate of diffusion of railway infrastructure across Europe. Britain led the world in railway technology and its contractors, engine manufacturers, engineers and entrepreneurs benefited from the resulting export boom. Britain had built $50 \%$ of its eventual maximum network length by 1863. Using this degree of network saturation as a benchmark, we see that the rate of "catch up" with Britain by other European countries varied by up to 50 years. The State played a critical role in the technology diffusion process in each country. The State was variously owner, guarantor, contracting authority, and concession grantor. The private sector was always involved as contractor and usually as operator. Many private companies formed to build railway lines were listed on the London Stock Exchange which was the main source of private capital, followed at some distance by the Paris Bourse. 


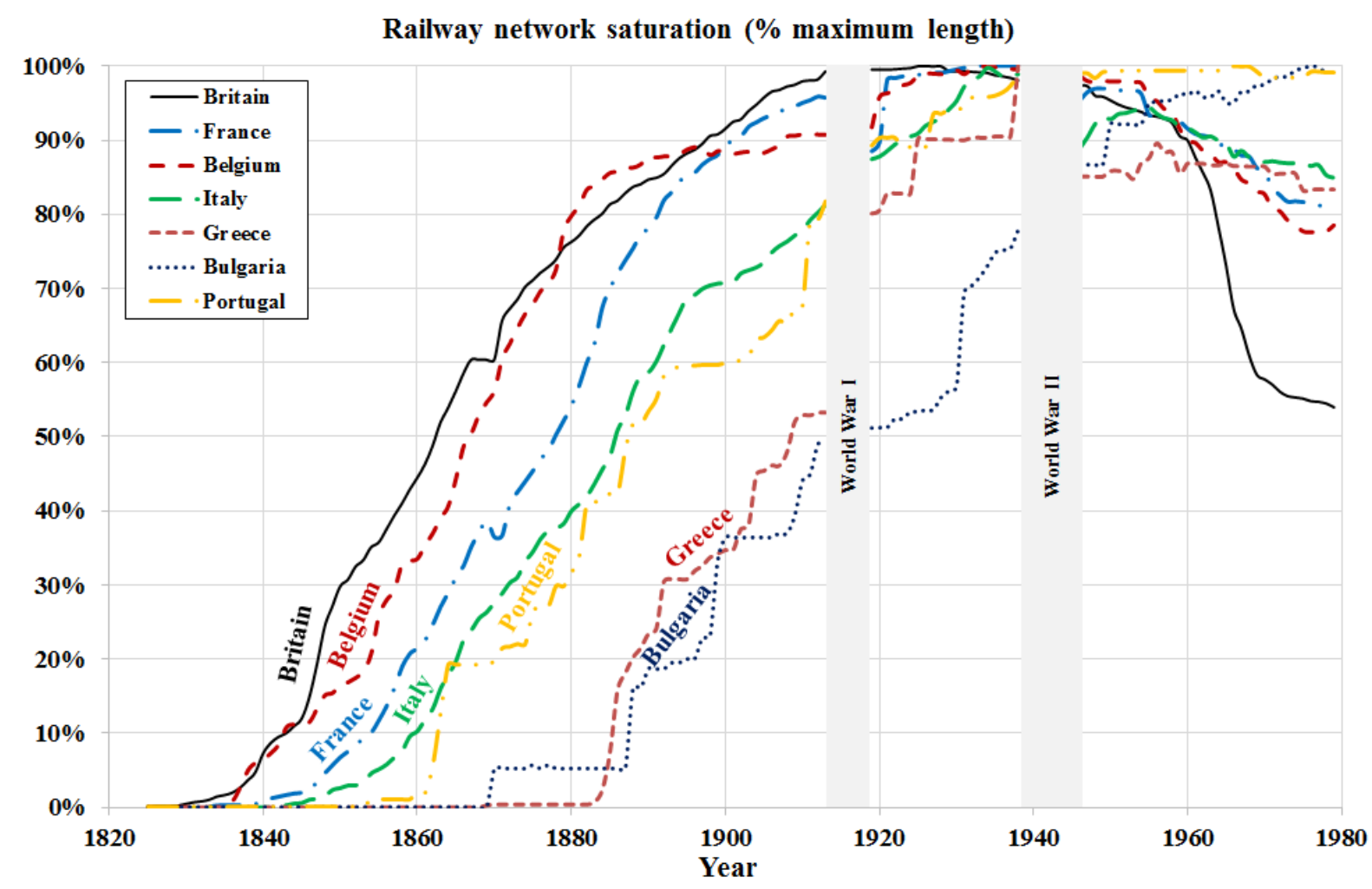

Figure 3. Growth and diffusion of railways across Europe

Source: Author's analysis based on data in Mitchell (1992)

Belgium was the first follower country to decide launch a national programme of railways as part of a State led industrialisation policy. The State launched new lines according to a plan to link the main industrial areas and ports. Railways were seen as strategically important both for military reasons and to help bind together the newly created nation. Only after the main East-West/NorthSouth axes were complete in 1843, were private companies allowed to construct and use their own lines. By 1867, Belgium had built half its eventual network, less than 5 years after Britain. Belgium continued to lead the industrial revolution in continental Europe until France and Germany caught up.

In stark contrast, Bulgaria did not reach 50\% saturation until 1915. In 1850, Bulgaria was still part of the Ottoman Empire, which prioritized development of railways in Turkey. The Turkish Government was permanently short of funds. In the 1860s they managed to attract British investors to build a line from Varna on the Black Sea Rustchuk on the Danube. The Turkish Government then signed a concession with an Austrian, Baron Hirsch, to build 2,500km of railways all over the region, including Bulgaria, Serbia and Bosnia. To attract a concessionaire, the Government promised a subsidy per $\mathrm{km}$ of construction, guaranteed revenues per $\mathrm{km}$ when operational and handed over the proceeds of a national lottery bond (Feis 1930, 293-212). The plan progressed very slowly. Northern Bulgaria achieved independence in 1878, but the south remained an autonomous Turkish Province. Only $224 \mathrm{~km}$ of railway line existed in the new country. Railways became a strategic piece in the game of diplomatic chess in the region. Even after independence, Bulgaria remained largely 
agricultural and suffered a succession of wars which made investors unwilling to support large capital investments like railways. The lines that were built were State owned or had a full State guarantee.

Across Europe, different patterns of State and private companies emerged to build the networks. There was no simple "model" of railway ownership and development across Europe. Political, economic and cultural traditions were too diverse. Those that built railways and industrialized fastest ended the century with the highest GDP per capita (Millward 2005, Chapter 4).

The US also decided to use railways as a strategic technology to build its nation. But, like Britain, it decided to let private companies own and build the entire network. This was achieved using subsidies and incentives on a massive scale, the most important of which were land grants. In the case of the first transcontinental line, high level corruption was involved through bribes to Congress to ensure favourable treatment in the 1864 Railroad Act (Rohatyn 2009, 49-73). As well as soft loans, the two competing companies building the line from opposite ends were given a land grant of 12,800 acres for every mile they built, and received full mining rights to the lands. The owners of the railway companies became extraordinarily rich. The line that joined the nation from coast to coast was completed in 1869 , fuelled by competition, cash incentives, land grants and government bonds based on performance. Despite the subsidies, the government still made a net profit on the deal.

\subsubsection{Telegraph}

Next came the wire based communications revolution started by the telegraph and continued by the telephone. The telegraph was invented more-or-less simultaneously in 1837 by Cooke and Wheatstone in Britain and Morse and Vail in the US, using similar technologies but different coding systems. Cooke and Wheatstone's system was immediately adopted by the Great Western Railway Company and telegraph wires run along the railway network as a way of signalling messages faster than the trains. In the US, Morse believed his invention should be owned by the Federal Government. But the US Postmaster General declined to purchase his patents, considering that the technology would never pay for itself (Friedlander 1995b). In the US, the news service, stockbrokers and eventually railways became major private clients of a highly competitive communications industry.

By 1861, the first transcontinental telegraph system was established across North America. In 1866, a US-British company laid a telegraph cable across the Atlantic establishing the first intercontinental communication system. In the same year, Western Union bought out its rivals creating a de facto monopoly for telegraph services throughout the US. By this time, railway magnates like Jay Gould and Vanderbilt had realised the potential and synergies of the new communications technology and were ploughing profits from railways into buying ownership of telegraph companies. In the UK, the private telegraph company using the Cooke and Wheatstone patents was nationalized in 1869 and became another service of the General Post Office (GPO), a publicly-owned national monopoly of postal services in Britain that had been established in 1643. 


\subsubsection{Telephone}

In 1876 , Bell patented the first commercially viable telephone. He started out working on the problem of increasing the capacity of existing telegraph lines, but realized that sending messages with multiple frequencies would allow him to transmit the sound of a human voice. Western Union declined to buy Bell's patents. As his first companies struggled for lack of capital, Bell drew further investment from William Forbes, son of another railroad financier looking for new investment opportunities. Further technological breakthroughs came with the invention of the switchboard exchange in 1877 and the loading cell in 1899. A change from charging per connection to charging for each call helped establish a viable business model. Bell used its patent monopoly and profits to expand both nationally and internationally and to buy up rival technologies. Bell established one of the first corporate R\&D laboratories that went on to become a model of how in-house R\&D can solve business problems (like the loading coil) and help retain a competitive advantage. The company was restructured to separate long distance from local services and AT\&T became the holding company for a series of regional operating companies. It took time, but the telephone would eventually kill off the telegraph.

Globally, household connection rates for the telephone progressed slowly compared to water, gas or electricity. Connections were expensive and the fewer people connected, the less valuable was the service due to network effects. The market penetration rate, expressed as the percentage of households with a fixed line telephone connection, only reached $50 \%$ of households in the UK in the mid-1970s, some 30 years later than the same level was reached in the US. However, from 1920 onwards the GPO ensured that the service was widely available across the UK by gradually installing "public" pay-per-call telephone boxes throughout the country.

Competition in telephone services continued in the US up to at least 1920, but a careful corporate strategy by AT\&T and the growing influence of regulation eventually allowed it to establish an effective national monopoly by 1924. The 1907 Public Utilities Act placed gas, heat, electricity and telephone services under the Railroad Commission, which had powers to set prices based on the cost of service. The US Government had briefly taken over the telephone system during WWI, but after returning it to private ownership, it accepted the argument that public services could be provided by a private sector monopoly as long as there was a system of strong regulatory controls to protect the public interest (Friedlander, 1995b). AT\&T's monopoly of local and long distance telephone services was finally broken up in 1982 in a compromise deal with the US Antitrust Authorities.

The first European company formed to exploit the Bell patents was established in England in 1878 after Bell personally demonstrated the telephone to Queen Victoria. However, the GPO rapidly obtained a legal judgement that telephone conversations came within its remit and required licencing. The private National Telephone Company consolidated its service by buying up any smaller companies. By 1896, the UK telephone service had been nationalized and brought within the ambit of the GPO. The strategic importance of all forms of communications would be confirmed by the 
outbreak of war. Telephone services were separated from the GPO in 1981 as British Telecom, and then privatized again in 1984 .

\subsubsection{Electricity}

The other world-changing infrastructure system to be invented in the $19^{\text {th }}$ century was electricity. In 1879, Thomas Edison registered a patent for an "economic" electric lighting system that envisaged a power generating station, a network of conductors, a meter and several high resistance filament lamps. Unlike his earlier British competitor Swann, Edison was not just looking to manufacture light bulbs: he was developing an integrated lighting system to compete with the gas lighting companies. Earlier inventions for electric arc lighting and the incandescent electric filament lamp had achieved some commercial success between 1879 and 1884. In 1882, Edison demonstrated the world's first integrated generating station and lighting system at the offices of his financial backers on Pearl Street in New York. From 1880 onwards, Edison formed a series of companies to control patents and deal with different aspects of the business, notably manufacture and distribution, both in the US and overseas. His major financial backer was JP Morgan, who had started out financing railways and went on to gain financial control of telephones as well.

Edison's business model was to gain a technical monopoly through patents, to licence local utility operating companies, equip them from his own manufacturers, and then accept payment in shares from the new utility. The US financial panic and crash of 1893 left many stocks near worthless and left the company in a crisis. JP Morgan engineered the split of the manufacturing equipment arm of the company to become General Electric. Edison remained wedded to the idea of a utility company supplying services.

Overseas, the various Edison companies founded between 1882 and 1885 went on to become dominant players in national electrical industries. Deutsche Edison Gesellschaft was formed in 1883 to construct the first generating stations in Berlin. The company was reorganized in 1887 as the Allgemeine Elektrizitats-Gesellschaft (AEG). The Comitato per le Applicazioni dell'Elettricita Sistema Edison in Italy constructed the first central generating station in Milan in early 1883 and is still a powerful presence in the Italian energy sector as Montedison. National networks were rolled out at a pace dictated by both economics and political considerations. Electricity started out as a local municipal service like water and gas, but the economies of scale argued for consolidation and eventually the need to construct integrated networks at a national scale.

In the UK, the world's first National Grid connecting the network to all major power stations was established in the 1926 Electricity Supply Act. It was complete by 1935 . The industry was nationalised in 1947, and the Central Electricity Generating Board set up in 1958. The world's first full-scale nuclear power station was opened in Cumbria in 1956. The network was privatized again in 1989. 
In the US, the networks remained mainly private, but increasingly heavily regulated at the State and from 1935 at the Federal level. By the 1920s, the rapidly growing US electricity utility companies were making extensive use of opaque holding company structures to raise large amounts of debt finance to fund expansion, but with very low amounts of equity, a technique learned from railways. A number of highly leveraged companies collapsed during the Great Depression, leading to tighter financial regulation. A persistent problem in the US was that power companies would not expand services to the rural poor, because they saw high costs and potentially low revenues per customer.

As part of Roosevelt's New Deal measures, the electrification of rural America was pursued as a policy goal. This was achieved with an innovative policy mix of supply and demand side measures relying on cheap power from the government backed Tennessee Valley Authority (TVA) hydroelectric scheme, construction of municipally owned power stations, and loans and loan guarantees to support small scale electricity cooperatives. The Rural Electrification Authority combined cheap long term loans for electrification with household loans to purchase the farm and household equipment that ran on electricity. In 15 years, the rate of rural electrification went up from $10 \%$ to $50 \%$. This was a classic example of using cheap government loans to kick start the economy with everyone winning. TVA sold more power, the equipment manufacturers sold their products and the quality of life of rural farmers increased. It overcame a market failure caused by the reluctance of big private electricity utilities to invest despite longer run social benefits.

\subsubsection{Tramways}

The last transport boom of the $19^{\text {th }}$ century came from combining rail technology with the power of electric motors, offering a solution to the growing problems of urban transport in rapidly growing cities. The use of horse drawn, then steam powered and cable pulled vehicles on rails for public transport predated railways by several decades. The first horse drawn tramway operated in 1804 in South Wales, UK. US cities led in developing the early technology before electricity, with New York starting a regular horse drawn tramway service in 1832. But until 1862, only France, Britain and the US had cities big and rich enough to afford tramways. The electric tramway boom that spread versions of the same technology to almost every major city in the world started in the 1880 s with a line built by Siemens in Berlin. Versions of the technology proliferated, but soon became a specialisation of Belgian capital.

Belgium had been the first country after the UK to industrialize and from 1870 its bankers and industrialists were starting to be interested in foreign investments. A tramway investment boom occurred in Belgium between 1895 and 1900, with 62 overseas tramway companies formed and successfully floated on the Brussels' stock market. They were formed following successful tenders for concessions, with or without competition, and relied heavily on Belgian capital and Belgian manufactured equipment (Lopez, 2003). The tramway financial bubble burst with the onset of WWI. 


\subsection{0 to 2000: Back to the present}

In the Age of Extremes between 1914 and 1945, two World Wars, anti-trust legislation, the end of the gold standard, hyperinflation, and the Great Depression saw many private companies go bankrupt. Changing social and political values resulted in nationalisations or government led initiatives. State provision became the dominant model for "natural monopolies". Much financial paper became near worthless as inflation ate away value, local politicians were reluctant to raise tariffs and foreign owners of basic services were not very welcome. In the midst of the Depression, Roosevelt's New Deal used infrastructure investment as a positive force to restore jobs, growth and prosperity. Post WWII, the Marshall Plan helped rebuild Europe's shattered infrastructure.

After WWII and a long period of infrastructure being owned and run by the State, the pendulum swung back in favour of privatisation in the 1980s with UK in the vanguard. Summing up the experience of the UK privatisations in utilities and other infrastructure between 1980 and 1997, Parker concludes: "The lesson of the history of both nationalisation and privatisation in the UK is that the propensity of Governments to intervene in industries is a function of the performance of the industry and its consequences for public welfare, both when it is publicly owned and when it is privately owned" (Parker 2012, 528). Overall, Parker concludes that it is difficult to pass a judgement about whether performance improved more than it would have under continued public ownership because of the lack of a counterfactual.

The State went from being an owner to being a regulator and contracting authority for infrastructure services. New independent Regulators had to learn from their mistakes, but the new systems of incentive based regulation delivered investment. Services improved due to more investment and better management. Efficiency gains were most likely when there was increased competition or more effective regulation. Measurable productivity improvements were greatest in those sectors subject to some form of competition, notably telecoms and gas (Newbery 2002). Newbery concludes that all modern network industries, whether private or publicly owned, must operate under rules set by the State due to the implicit tension between the political interests of investors and those of consumers in industries with both high sunk costs and high welfare sensitivity.

\subsubsection{Wireless}

Marconi patented the first wireless communications device in 1896 and then demonstrated that he could transmit a signal without wires over several $\mathrm{km}$. In 1901, he transmitted a signal across the Atlantic. Over the coming decades public broadcasting was established in most advanced countries for one-way mass communication. The technology continued to evolve until the mobile phone allowed telephones to escape the fixed wiring, with the first chord free handheld device offered to the public in 1973. 
Building out mobile phone networks was led by private capital. This works because of the relatively low capital cost of establishing the network and what turned out to be a high willingness to pay, first by business then by private users. Once spatial network coverage is established, rich and poor are covered alike and can simply choose a different level of service and user device to reflect their needs and budget. The diffusion of low cost and reconditioned mobile phones into the developing world, combined with pay-as-you-go services has meant that mobile phones have achieved the fastest global network expansion in the history of infrastructure. However, those who claim mobile technology can teach something to those worrying about basic public health services in Africa fail to understand the physical weight difference and resultant cost implications of distributing a cubic meter of water compared with a gigabyte of digital data.

\subsubsection{Airports}

Airports are a recent form of transport infrastructure driven by technological innovation. Following the Wright brothers first powered flight in 1903, take-off and landing facilities moved modestly on from a field to an engineered strip with ancillary facilities. Major advances occurred during the two world wars.

There are several contenders for the first commercial airport as sites established during WWI were later converted to civilian use. Maryland, Bremen, Rome and Paris all have a claim. Hounslow Heath Aerodrome near London was the first airport to operate scheduled international commercial services in 1919. Both public and privately owned airports were established over the coming decades. All were converted to military use during WWII. Many technological innovations were introduced after WWII, but the real boom occurred after 1970 with the introduction of low cost, mass market international charter flights to support the growing tourism industry. Britain's airports were privatized in 1987.

\subsubsection{Motorways}

By far the largest capital investment in new infrastructure networks since WWII has gone into building motorways, either been financed by the State directly or via concessions, with or without tolls charged to road users, see Ragazzi and Rothengatter (2005).

The world's first public motorway opened to traffic in 1924 in Italy. The 40km Autostrada dei laghi linked Milan to Varese and was later extended to Como. It was privately financed and introduced tolls from the start. The early Italian fascist government had a policy of privatization and using private concessions for public works, including motorways (Bel 2011). Italy completed 5 other major motorways before WWII. Germany followed the Italian lead and completed its first autobahn between Cologne and Bonn in 1932. In 1933, the newly elected Nazi party launched an ambitious autobahn construction programme that built $3300 \mathrm{~km}$ of motorways by 1939. As well as developing a 
national network that served military as well as commercial purposes, it employed over 100,000 labourers during construction and supported the nascent German car industry.

Post WWII, building motorways became part of the post war reconstruction of Europe. A common European specification for motorways was agreed in 1957. By 2010, the total length of motorways in the EU was $68,000 \mathrm{~km}$. This represents less than one third of the length of railways and is still less than the maximum length of the paved Roman road network. Since the 1990s, experimentation with various forms of PPP arrangements for private financing of motorways has been popular.

3.7.4 Internet, broadband and the worldwide web

The latest global network grew organically out of initial projects funded by the US military such as ARPANET and enthusiastic uptake by academics around the world as a way to share information. The key technological breakthrough was not a piece of physical kit, but a concept called packet switching. Whether these technologies should be called physical infrastructure and whether the services they provide are communication, information or knowledge is a matter for debate. Abbate (2000) argues persuasively that the Internet was shaped by social and cultural factors that defy simple narratives of production and use.

Broadband is a way of delivering far greater capacity to the Internet and other digital services and can involve wired, wireless or optical technologies. Rolling out coverage of high speed broadband to rural areas is reawakening all the old challenge about how to overcome the reluctance of private companies to invest in areas of high cost but low potential revenues, challenges that were already faced by water, gas and electricity and overcome by regulation, subsidies or public ownership.

\section{Technological, financial or institutional innovation?}

With the historic narrative presented, we can now explore the relative importance of technological, financial and institutional innovation in driving the major changes in transport, water, energy and communications infrastructure services.

In the ancient world, the City and then the Empire State was the major driver of all infrastructure projects. Command and control policies built civilizations. The economic role of slavery was important for major works, but paid labour was also used. A legal framework evolved that dealt with risk and contractual debt. The benefits of infrastructure were shared to some extent with the population, but at far lower standards of service than the King/Emperor or social elites. With the exception of the Indus Valley civilization, water and sanitation services to private households remained the preserve of a privileged few. However, water was a public good available for free at public fountains throughout the City. The needs within cities and the need to connect cities defined infrastructure. Large amounts of resources went into temples, pyramids and other monumental public 
buildings with no immediate economic purpose, even if in the very, very long run they generate employment in archaeological tourism!

The Persians and Greeks introduced many institutional innovations that improved infrastructure services, including the use of private contractors for public works. There is evidence of project finance having been used for the first time by Greek City States and the first large scale private infrastructure programme for qanats across Persia. Legal provisions covered both public and private rights and obligations in relation to infrastructure. A long distance road transport and communication system was in place by around 500BCE, but the major user was the State itself. Taxes on the transport of goods were an important source of State revenues.

The Romans developed a military and infrastructure led model of conquest and development that created an Empire lasting over a thousand years, at least in the East. Trade flourished. The State led all major infrastructure construction with funding from general taxation. Once built, each City was supposed to maintain the infrastructure services within its walls. The road network was built by the military and private contractors. The system of maintenance for roads and aqueducts was completely reorganized by Augustus to concentrate power and clarify responsibilities. Private contractors for civil works flourished on a diet of construction and maintenance contracts. Slaves made up a significant part of the workforce building and operating networks. Technological innovation was more about scale and ambition rather than new invention, although waterproof concrete was an important advance. At the high watermark of the Roman Empire around 120CE, the diffusion, scope and quality of infrastructure services reached a highpoint that would not be regained until the $19^{\text {th }}$ century.

From 1500 onwards, private capital started to play a part in infrastructure. All of the water supply and transport revolutions over the coming 400 years had private investment playing a leading role. There was very little in the way of "technological revolution". Canals and pipes used old technologies, often inferior to that employed by the Romans. In road construction and maintenance, the focus was on efficiency rather than building to last. The first new road technology was not introduced until 1830, well after the turnpike mania years. The new materials of cast and then wrought iron transformed the technology for bridge construction, pipes and above all machinery with the invention of the steam engine.

Often there were huge lags, literally hundreds of years, between first use of an innovative infrastructure technology and its wider adoption. The turnpike mania started 90 years after the first turnpike. The UK's canal mania started 260 years after the first pound lock at Exeter. The New River Company was formed over 20 years after the first new water supply to London. The necessary condition for take-off to attract private investors appears to be a combination of suppressed demand and a financial "success story" to create a bandwagon effect. Private investments needed to be financially viable. The vision of individual system builders, such as Myddleton, Brindley, 
Stephenson, Morse, Edison or Marconi and their financial backers to take the initial risks played a critical role in the launch phase for each new system.

The picture changed dramatically with the railways. The new technology was adopted very rapidly and started a construction boom that covered the entire UK with railways within 20 years and the world within 70. What really facilitated the diffusion of railways globally was finance and the joint stock company. However, it is important to realize the important groundwork that had been laid by turnpikes and canals.

Private financing of infrastructure was a major factor in industrial take off in England after 1750 (Trew 2010). This involved a combination of financial innovation and institutional reform involving standardization in the way in which infrastructure finance was regulated through Parliament. The repeal of the restrictions of the Bubble Act in 1824 and creation of limited liability joint stock companies completed the transformation in time for the railway revolution. In finance, a positive feedback loop was established between savings, investment and growth. Early industrialists, mainly in Lancashire, funded local infrastructure from which they benefited directly. Then slowly as the capital needs grew, the centre of fund raising gravitated towards London. As the limited liability company format became successful, it expanded the range of individuals trading in shares. Finally, the emergence of large railway companies with huge capital needs facilitated the emergence of a centralized London stock market, which in turn began to direct surplus savings into all forms of profitable industry and soon to investment opportunities overseas.

Competition started to play a critical part in the early stages of all new private infrastructure services where there was a potentially lucrative market. Competition could either be between alternative technologies or for the monopoly of a service area. There was also competition between cities and between nations to be the first to adopt a new technology. Even in water supply, a dynamic market developed with 29 private companies supplying Greater London at different times until consolidation reduced this to 8 local private monopolies and finally a single publicly owned service provider (Goldsmith forthcoming).

In the railway sector, where companies faced competition from canals they would frequently purchase the canal and either let it run down or in extremis fill it in and build a railway on top. Competition between companies was fierce to capture travelers. But there was no interest in collaboration and coordination on issues like timetables or through ticketing until either companies merged or cooperation was imposed through regulation.

Fueled by competition and financial frenzy, Britain overbuilt its railway network until it became the densest in the world. Huge amounts of capital were wasted due to duplication of lines and inefficiency caused by weaknesses in government regulation and defects in policy (Casson 2009). Several authors contrast the extreme laissez-faire in Britain with France or Belgium where the 
Government took the lead in planning the core network on a rational basis. In Belgium, this was linked to a conscious plan to catch up with Britain in industrialization and to help unify a new nation. In Britain it was left to the market.

In the gas sector, the negative effects of competition in London led to Government regulation from 1860, first to allocate service area boundaries to avoid streets being dug up multiple times and then in 1868 to allow takeovers, amalgamations and less restrictions on companies' ability to raise debt. In return, a cap on profits was agreed at $10 \%$ and Government had increased financial scrutiny. In many other cities, the local councils bought out the gas company and ran the service themselves.

In the case of gas, electricity and telephone utilities most were consolidated and then nationalized by 1950, and the main investment drivers became efficiency, safety, network coverage, national strategic goals and building new capacity to meet ever rising demand. On top of that, in public ownership they were under political pressure to limit rises in user charges. Technological innovations were adopted in so far as they helped achieve those objectives, such as the switch to natural gas or the construction of nuclear power stations. Millward (2005) explains how contradictory, multiple objectives placed on managers of State Owned Enterprises (SOEs) were one of the factors that eventually led to privatization and deregulation.

From 1800 onwards, revolutions in infrastructure services became technology driven and almost exclusively led by private entrepreneurs. Once a new infrastructure technology had been invented, the problem was always how to raise the funds for service expansion and diffusion. Once a technology had taken off in one country, competitor nations were quickly looking at how to follow the leader. If a new infrastructure was perceived as strategic, then the State would try to get it built, first with private capital and then if that failed with guarantees, other incentive mechanisms or eventually through public ownership.

A similar dynamic of competition and follow the leader occurred with municipal services, but with very different development paths in each country. Once one city had introduced gas lighting, water supply, or electricity others rushed to follow suit, either via private concessions or municipally owned companies. The variety of public, private and mixed ownership models for municipal enterprises across Europe is remarkable for its diversity. The different legal framework for municipal services in each country also played an important part in directing the trajectory of ownership and scale of development. In Germany, publicly owned, semi-autonomous, multi-utility companies, called Stadtwerke, became the dominant model for citywide utility services that persists into modern times. In France, fragmented autonomous communes let out their municipal water services to private companies, first through concessions and then gestion déléguée contracts. Economies of scale were achieved by the private concessionaires themselves, with industry consolidation eventually leading to the creation of the two French multinationals that dominate the international private municipal service industry today. 
Telegraph, telephone and electricity were all technology driven innovations based on a better scientific understanding of the potential of wired electricity to transmit signals and power. Patents became a key instrument for gaining commercial advantage in the early years of network building. Competition between standards, such as the AC v DC current wars or the broad v narrow gauge on railways were common in the early years, but each industry trended towards standardization followed by economies of scale. The US managed to retain a vibrant private competitive market in telegraphy and until Western Union maneuvered a national monopoly. By contrast, in most of Europe communications was considered a strategic sector and was immediately taken over by the State.

To illustrate this story from start to finish, Figure 4 shows the birth, expansion, growth and decay of the main inland transport technologies in the UK. The length of the Roman paved road network in Britain was $3400 \mathrm{~km}$ at its peak, a length the modern motorway network only achieved in 1999. Each transport service revolution had its own actors and logic. Roman roads were State financed, built and maintained. Turnpikes were not-for-profits representing local commercial interests, paid for through tolls and raising debt from local investors by pledging future toll revenues. Canals repeated the financing model used for turnpikes, but this time with local investors as owners rather than trustees and providing mainly equity rather than debt. Railways rapidly became mass shareholder owned with equity and debt funds raised through the capital markets in London. Motorways were publicly owned and funded with no user charges, but there was a tax on vehicle ownership. Of the four transport revolutions shown, only railways could be considered as technology led. The pace of network expansion towards saturation is similar over time, but the lags between system innovations (shown to nearest 5 years) are irregular.

What Figure 4 does not portray is that the road network built by the Romans, paved and unpaved, never really went away. Certainly, paving materials were stolen for other building projects over the centuries. However, many turnpikes were built along the line of existing Roman roads. When the turnpikes were wound up in the 1880s, it was only ownership that changed, not the network. The roads transferred to local authorities who maintained and upgraded them, including a major trunk road upgrading programme starting in the 1920s using labour from high unemployment areas. When the motorway network was added starting in the 1950s, it only added capacity to the existing main roads, many of which were already dual carriageway.

The rail network has been reduced by almost 50\% from its maximum length in 1920 . Although rail use in terms of passenger-km increased year-on-year until WWI, thereafter it suffered a continuous slow decline as road traffic substituted rail. Demand only started to climb again after 1994. The smaller lines that no longer made economic sense were slowly closed until a major rationalization and closures took place from 1965 onwards. The latest capacity enhancement - High-Speed Line (HSL) - is not shown in the graphic. UK has only one line at present. The leader for HSL in Europe is France. 
When the privatised rail infrastructure company Railtrack failed financially in 2002 as a consequence of safety problems, the State stepped in to ensure continuity of service and a transfer of assets to a new not-for-profit entity, Network Rail. Infrastructure assets last, even if ownership changes or companies go bust, and the public sector always has to step in to keep the services running. The State becomes the de facto infrastructure service provider of last resort.

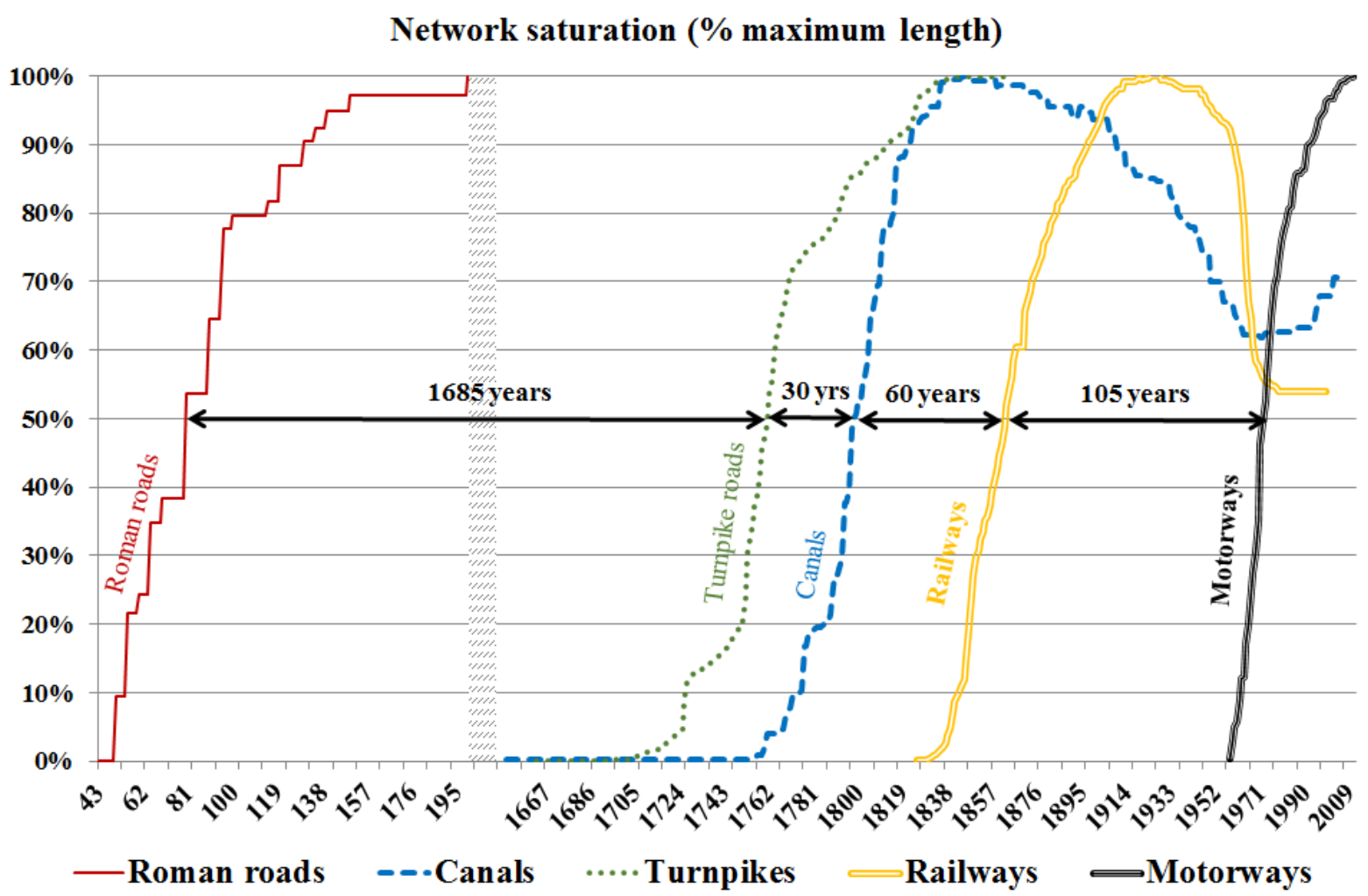

Figure 4. Growth and decline of UK inland transportation networks

Sources: Author's elaboration combining different sources. Length of UK railways from Mitchell (1992); Roman roads from Sitwell (1981); Turnpike data from Albert (2007); Motorways from Charlesworth (1984); where available data updated with recent figures from Transport Statistics Great Britain at https://www.gov.uk/government/collections/transport-statistics-great-britain.

The canal network suffered an even worse fate than the railways, with what looked like a terminal decline. The network was taken into national ownership as British Waterways Board (BWB) in 1962 with virtually zero commercial traffic. Many canals were derelict. From the 1950s onwards, leisure boating on the old canals started to become popular and a non-governmental organization of enthusiasts started a campaign to keep canals open and restore them using volunteer labour. The length of the network open for pleasure boats has been increasing since 1977. BWB has recently been transferred to a not-for-profit Trust. Should restoration of old canals with volunteer labour be seen as an innovation? For the public, the scale and quality of services is improving.

So in the country that started the modern transport revolution with not-for-profit Turnpike Trusts 250 years ago, two of its earliest major networks, canals and railways, are now owned by notfor-profit bodies. At the same time, major new projects are being structured on a project finance basis, with or without State guarantees. The importance of innovation is increasingly being factored 
into public procurement of infrastructure, with the latest underground station refurbishment contract in London awarded through a competitive tender in which the degree of innovation was a significant factor in winning the bid.

\section{The phases of infrastructure innovation}

Adapting Freeman's categories of innovation (Freeman 1992; Freeman and Louçã 2001) to infrastructure services, we can identify four distinct types of innovation by their scale and speed of diffusion: incremental innovations that bring minor improvements to a part of the overall system; radical innovations involving a reconfiguration of existing technological systems; disruptive innovations that introduce a whole new way of providing the service; and changes in overall technoeconomic paradigm leading to new forms of production, consumption and economic organization.

Incremental innovations are the small scale changes that improve the performance of a system in terms of efficiency, capacity, quality and/or cost. For physical infrastructure, incremental innovations are closely linked with the day-to-day processes of replacing existing components with new ones rather than replacing like-with-like. Central to the decision whether to innovate is the life and serviceability of the existing asset. Optimized asset management planning has become a central concern of public and private infrastructure operators alike. An efficient operator should always be looking to adopt innovations of this type, especially if they are cost saving. However, if they are financially constrained to invest in asset replacement there can be a tendency to "sweat the assets" rather than modernize.

Whilst technological innovations are the most visible, in a world of high labour costs, changes to the "soft systems" of how infrastructure is operated can potentially bring big savings or service quality improvements. Another important way of gaining efficiencies is through economies of scale or scope. Examples include consolidation of railway companies in the $19^{\text {th }}$ century or water companies in the $20^{\text {th }}$ century and the emergence of the private multi-utility model in the $1990 \mathrm{~s}$.

Radical innovations involve major changes to the way a system is configured or operates. An example would be the introduction of nuclear power plants for electricity generation in the USSR, US, and UK in the 1950s and 1960s. For users of electricity, the source of power generation is not directly experienced so it has no immediate impact on the quality of service. Historically, such radical innovations are often associated with new regulatory requirements or major policy shifts, such as France's decision to go nuclear for energy production after the 1973 oil price shock or the current switch to renewable energy sources. Environmental infrastructure investments in wastewater treatment and solid waste have largely been driven by new regulations. Economic factors signaled by relative prices can also be major drivers, such as the "dash-for-gas" switch to cheap gas fired power generation in the 1980s. So such changes can be technology driven, regulatory or price driven. 
Disruptive innovations are the invention of a whole new way of meeting a basic infrastructure service need. The classic examples would be railways replacing canals, cars and tarmac roads replacing railways, electric lighting replacing town gas or mobile phones replacing fixed lines. These are innovations that have systemic implications as they open up whole new ways delivering services. Of course, the pattern of use does not change overnight. It takes time to build out the new networks and the old incumbents can respond with aggressive price competition to try and survive.

Not all disruptive innovations are competitive and ultimately destructive to existing infrastructure systems, but can actually trigger new waves of innovation. Canals were partially complementary to turnpike roads as they only took the heavy freight traffic for bulk materials or bulk manufactured goods off the roads and were not used for short journeys or for passengers. Similarly, the invention of the internet gave a respite to the fixed telecoms operators faced with competition from mobiles as they could now offer new ADSL services over phone lines. In fact, the survival strategies of "old" infrastructures faced with new competition can lead to a new wave of innovation. When the town gas monopolies were faced with being made redundant by the invention of electric lighting, they responded by reinventing themselves as suppliers of gas for cooking and heating.

Diffusion refers to the expansion of the application of a technology in space over time. Rogers (1962) theory of the diffusion of innovations has gone through various refinements over the decades, but the essential story remains the same. Invention of new technologies is followed by an Scurve growth in market uptake, which starts slowly with a few innovators, reaches a take-off point of rapid market expansion through take-up by early adopters, after which it accelerates with growing profitability and market penetration, followed by a final phase of the slow tail of laggard late adopters. Finally the innovation becomes outdated and is replaced by a new cycle of innovation. This model needs to be adapted for infrastructure services, because adoption is dependent on the physical network being expanded over a geographical area rather than the sale of a product and hence government policy plays a critical role. Infrastructure's customers are not just individuals, but cities and even nations.

The institutional and financial regimes governing how infrastructure is planned, built and services delivered have a direct impact upon the socio-economic efficiency of investments (Prud'homme 2005; Estache 2007). The potential channels of influence are many. Without an adequately functioning financial system of banks, capital markets or access to development grants, potentially beneficial projects simply won't get built. If public authorities are incompetent or corrupt they may build the wrong project or choose a shoddy contractor in order to maximize bribes rather than welfare. Planning delays or inefficient procurement may endlessly delay the investment. A public utility with inadequately trained staff may not operate the assets well. If user tariffs are kept too low for political reasons, the service may enter a vicious spiral of insufficient revenues leaving 
insufficient funds for maintenance leading to deteriorating services and an even lower willingness to pay by users. The quality of infrastructure investment is important, not just the amount spent.

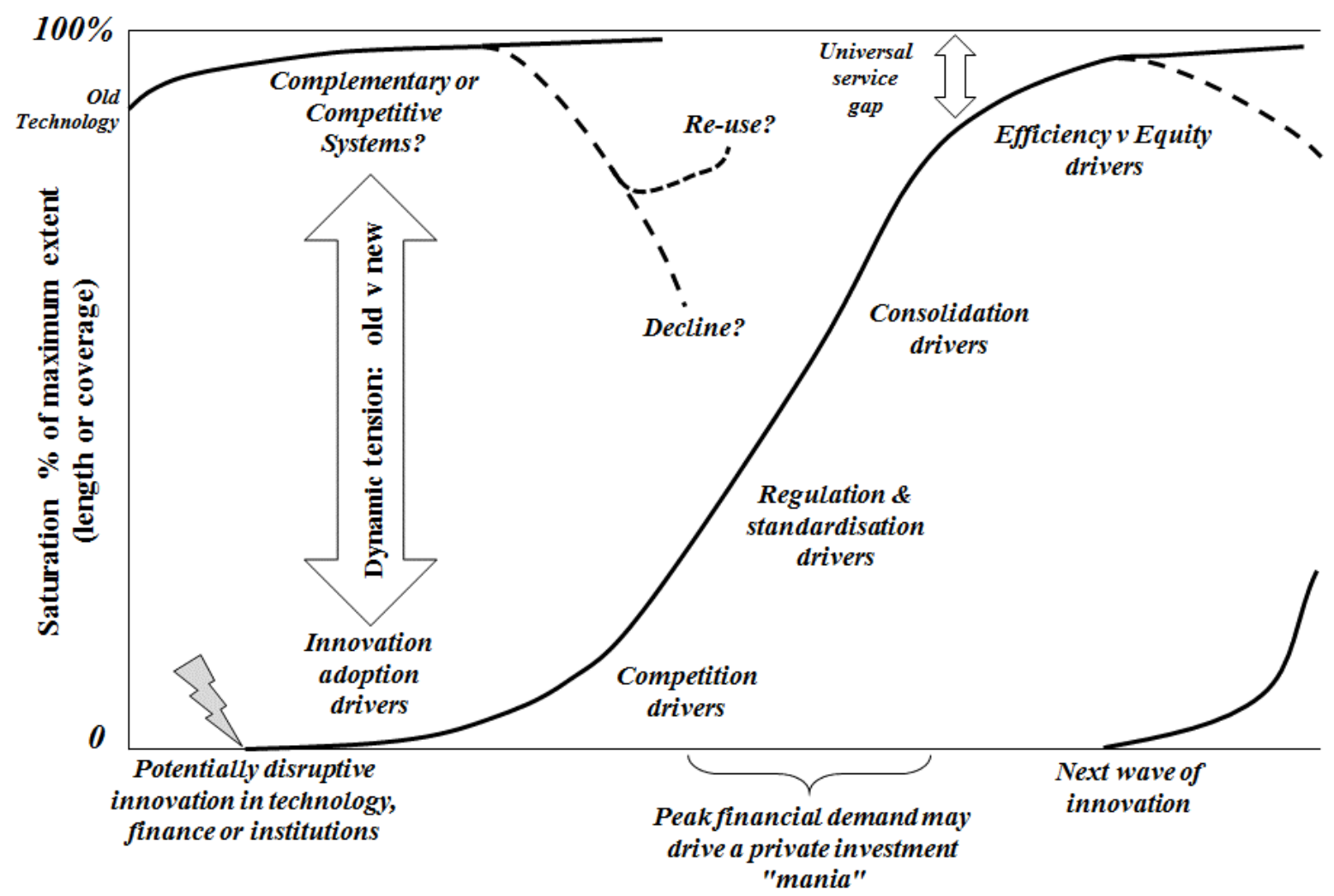

Figure 5. The inf rastructure innovation cycle

Figure 5 presents a synthesis of the innovation cycle for a typical infrastructure network expansion. Each stage of the cycle has different innovation drivers. The cycle starts with a new technological, financial and/or institutional innovation that challenges existing ways of delivering services. At the start, either an existing mature network provides the service (as with canals prior to railways) or the need is met by a non-network solution, such as oil lamps prior to the invention of gas lighting in 1810. An innovative technology opens up new possibilities to meet that demand at lower cost. If the cost savings are significant (or could be if the network achieved scale), then it would make sense to build the network. If the existing service is private and operated for profit, then there will be strong incentives to develop the new technology to capture profits. Sometimes the new technology is not competitive, but complementary, such as canals with turnpikes or broadband with fixed telephone lines. A pilot project goes ahead and demonstrates viability. Success attracts investors, but also potential competitors. As we have seen, the lags between invention and large scale deployment in one country and diffusion to others can be very long.

The drive to expand services proceeds through 6 phases. The first stage starts with a disruptive innovation that can be technological, financial or institutional. In a leader country, this stage is often led by a new technology. In a follower country, the existence of the new technology is known so the innovation can become a policy choice for the public sector. If private actors are 
already proposing the new technology then it may make sense to "leave it to the market". This is what happened with mobile phones in Africa. But if the market is not working, then the State may decide to intervene either to encourage private investors or as an owner and investor in its own right.

Next comes the period for competition if there are competing technologies or if other private firms are competing for the service. Then comes the onset of a need for standardisation and regulation. Historically, regulation has been a major driver of innovation as it forces service providers to meet tougher quality standards and imposes costs.

Next comes the period of most rapid expansion and peak demands on the financial system. The dynamics here are very different for a private investment opportunity, when indeed a speculative bubble may develop, or with public promoters, who may struggle to raise funds. The critical point is that the period of peak financial demand is constrained by the ability to raise funds, whether public or private sector. This phase has played out different in different contexts. In the UK for canals and railways it was possible to raise private investment funds. In Bulgaria, this required a State guarantee and other incentives to attract private capital. Towards the end of this stage, there is usually a strong push towards consolidation to reduce costs.

After this phase, the network is largely built and two new dynamics come into play. Firstly, there are the on-going efficiency drivers to generate higher profits or to keep user tariffs low. Either way, the network operator should have incentives to innovate. The other driver is a political one towards universal service, i.e. that even the poorest or most remote areas are given access. Innovative ways to achieve this could involve adapting service standards in low income areas, or working with a tight budget constraint. Finally, the next disruptive technology comes along and the cycle starts again.

\section{Confronting theories}

How well does economic theory fit the stylized narrative above? Neoclassical economics is focussed on markets, competition, choice, relative price and the behaviour of rational, optimizing economic agents. It is essentially a static theory, despite new growth theorists having used the magic of logdifference equations and the strange economics of knowledge to explain growth. As an economic theory it does not capture the complexity, innovation and adaptation we see in the real world (Nelson and Winter 2009).

Nonetheless, the neoclassical tradition remains powerful and new endogenous growth theories have sought to internalize infrastructure and human capital accumulation as important variables in the aggregate economy-wide production function, usually paid for through taxation (Barro 2003; Agénor 2007). A recent review of the infrastructure and endogenous growth literature concludes that "the theoretical studies modelling infrastructure within endogenous growth models, whether as a flow or a stock variable, tend to disregard the indirect effect that infrastructure has on some measure of output via TFP” (Dissou and Didic 2013, 42). 
In all such models, growth is essentially more of the same not long term change in the structure of the economy. The change in the world economy between 1820 and 1870, between 1870 and 1920 and between 1920 and 1970 is not simply a growth in the amount or output of the same old stuff, but rather a fundamentally different pattern of production of new as well as old things, supported by radically new infrastructure systems.

This paper has sought to demonstrate that infrastructure services change dynamically in tandem with the real economy, but change occurs slowly over decades and sometimes centuries. For socio-political reasons, infrastructure services have frequently been provided at zero price to users, thus falling outside the realm of price based market clearing mechanisms. Many of the benefits of infrastructure, such as "quality of life", are hard to quantify in market terms, but do really affect wellbeing and have a measurable effect on welfare and behaviour. Prud'homme (2005) makes a strong case that the concept of capital was never designed to be applied to infrastructure and that the standard production function is inappropriate for modelling it.

What of new institutional economics (NIE), and particularly transaction cost economics (TCE)? North pioneered the view that economic change needs to be seen in a long run perspective where institutional innovations are as important as technological progress (North 1990, North and Wallis 1994, North 2006). NIE is an eclectic tradition that embraces institutions, property rights, contracts, regulation, politics, asset specificity, etc. Different infrastructure sectors have been examined by a range of authors, who try to go beyond "institutions matter" to look at systems of government, contract and regulatory design and their impact on outcomes. They find a huge variety of outcomes in terms of the structure of vertical and horizontal integration of network industries providing infrastructure services, even when there are a common set of rules. History and path dependence play an important role in determining how industries are organized and regulated.

Given the importance of regulation, doing it well should be a major concern of governments. History can offer many clues to how and how not to regulate private infrastructure services. GomezIbanez (2009) argues that credible long term commitments are at the heart of the regulatory bargain between private investors and the State. Without such credibility, there may be an inevitable cycle of oscillations between public and private ownership.

An important insight from the TCE tradition is that running markets has a cost and therefore that anything lowering those costs will increase the efficiency of markets in solving social resource allocation problems. At a macro-level, this is where infrastructure really gains traction as a driver of efficiency. Lower transportation, energy, water and communication costs feed through to all aspects of economic activity. For firms, it lowers the costs of inputs and the costs of getting their goods or services to market. Better transportation enlarges markets. For households, it can lower prices and increase the choice of goods available, because they can come from wider markets. It lowers the costs of traveling to work and the effort needed for household work, thus freeing more time for productive 
activity or leisure. Safe drinking water in the home saves time, reduces mortality, and brings a huge improvement to quality of life. Environmental infrastructure makes our cities more livable. For governments, it can make the cost of administration and coordination lower. And then there are the systemic long term benefits to human capital resulting from better education and healthcare that school and hospital infrastructure supports. Of course, you can have too much of a good thing and infrastructure is not immune to the law of diminishing returns. So saying "no" to the unjustified incremental investment project is an important role for private investors, governments and development banks.

The evolutionary growth-substitution models of infrastructure proposed by Grübler (1990, 2003) offer the closest fit with the details of innovation, growth, diffusion, saturation and decay that we see in history. He emphasizes how infrastructure expands, has to find new forms of organization to deal with the coordination problems of scale and also how institutions have to adapt to the new economic reality. He found similar patterns of infrastructure growth in socialist USSR as in the US, which for him confirmed that infrastructure services were independent of a particular economic system for organizing society. The longer term historic perspective presented here supports that view. China currently has the fastest expanding infrastructure networks anywhere on the planet, because it can afford to spend and its people expect better infrastructure services, not because there was a new technological breakthrough or particular ideology.

There are a number of features where Grübler's model is less convincing. Firstly, he underplays the importance of relative price and quality of services both to firms and households as being decisive in early stage adoption of potentially disruptive innovations. The price-quality advantage was the critical factor that launched the canal and then the railway booms in Britain. Making transportation cheap and convenient from Manchester to Liverpool suddenly made a weekend at the seaside a possibility for those inland factory workers. Railways literally created new markets, first locally, then nationally and then globally.

Secondly, Grübler also claims that the regularity of major transport innovations provides support to the idea of 55 year Kondriatev wave long cycles. The longer term perspective presented here does not support this type of technology driven determinism, see Figure 4. Many of the early infrastructure network revolutions were effectively reinventing the technology well known to the Romans. Moreover, the turnpike revolution grew more slowly than is portrayed, starting well before the industrial revolution and beginning with an innovation in financing not with technology.

Fouquet (2008) has expanded the earlier analysis of Nordhaus on the long run cost of providing lighting services to estimate changes in costs and the corresponding prices of services for both energy and transport in the UK over the last 700 years. He demonstrates that new energy sources and transport systems develop in response to changing price signals. It is the relative cost of one technology over another than drives the long run substitution effect. But crucially, this only applies 
when infrastructure is charged for and market forces are at work. The impact of this technological progress on the price of services is illustrated in Figure 6. Starting in 1800, the cost of lighting services fell due to the substitution of gas for oil lamps. The trend continued with the substitution of gas by electricity and further by increasing efficiency and scale economies in electricity generation and distribution.

Fouquet traces a similar pattern for the reduction in the price of transport services based on energy and time considerations as the truck replaced the train which had replaced the barge which had replaced the horse drawn cart etc. The long run impacts of such systemic efficiency gains over the long run can be dramatic. Bogart (2012) found freight charges in Britain decreased by 95 percent in real terms from 1700 to 1870 implying an annual total factor productivity gain of more than 2 percent.

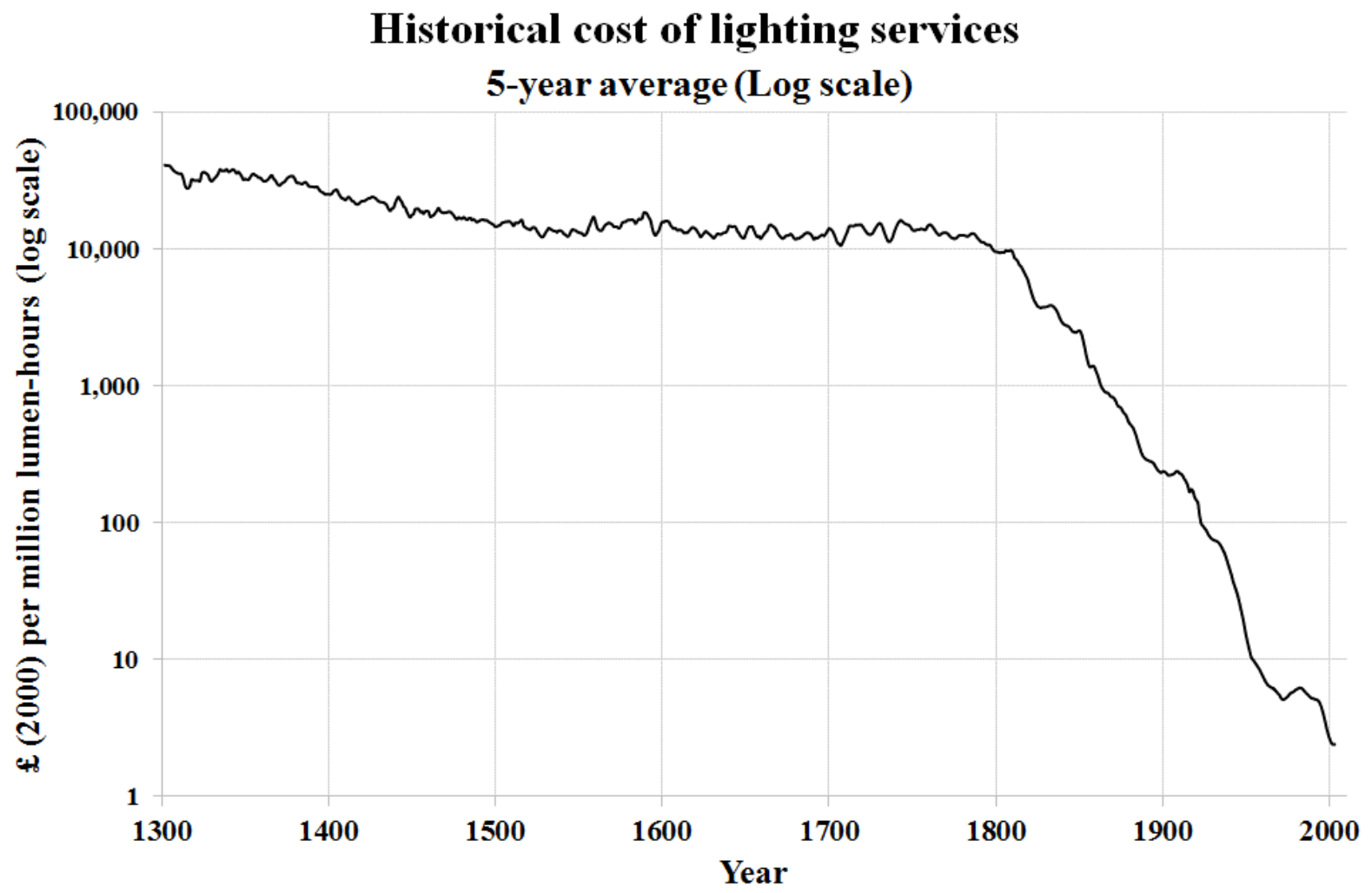

Figure 6. Long run trends in the cost of lighting services

Source: Data in Fouquet (2008)

In a simplistic version of this story, technological progress drives the whole process and network infrastructure is just a particular way to provide low cost services by exploiting economies of scale. That would fit the recent mobile phone story very well. But it does not explain why canals, a technology that had been known in the UK for over 200 years were not deployed sooner. It also doesn't explain why, once the advantages of a particular infrastructure technology are known, all nations don't immediately adopt it. One answer is that nations, like households, face a budget constraint. Finance determines what infrastructure gets built and is the key factor missing from Grübler's analysis. 
Perez (2002) takes a neo-Schumpterian view of long run change in techno-economic systems. She adds the role of speculative finance to the technological innovations story. In her model, infrastructure is portrayed as a supporting actor in the drama of successive great surges of development (GSDs) driven by the interaction of technological progress and financial speculation in the capitalist market economy. She identifies five technological revolutions and resulting GSDs starting with the first industrial revolution and ending with the age of information and telecoms. Her model involves four phases of irruption, frenzy, synergy and maturity. Financial capital plays a critical role during the frenzy phase as it determines the speed of diffusion of the technology or infrastructure. However, Perez sees infrastructure is an externality that arises to support industry. Each GSD has "given rise to a whole set of new industries along with a set of new organisational principles and externalities of infrastructure and knowledge that enable the modernisation of practically all of the existing industries" (Perez 2010,4).

Perez model has all the crucial ingredients and positive feedback dynamics that we observe in the history of infrastructure development, but she considers it a theory of the overall techno-economic paradigm, not individual sectors. New techno-economic paradigms involve systems of innovation that affect the entire economic system and open up entirely new possibilities for economic activity based on a new "common sense" about how the economy works. Perez sees the interactions and particularly the positive feedback between technological systems of production, infrastructure, finance and institutions as the driving force of economic development in the long run.

A deeper look at the functioning of early capital markets suggests a rather more prominent role for infrastructure. The evolution of capital markets from funding State debt to finance wars or excessive consumption of the king to a system of risk based financing of infrastructure was one of the most important innovations in the history of economic development. By channelling the savings of the industries and workers who were directly benefiting from the lower transaction costs and overall increased efficiency of the system back into creating more infrastructure, a positive feedback developed that underpinned the growth shift we see starting in the $1800 \mathrm{~s}$.

Excluding domestic and foreign Government debt, of the 70 companies whose stocks and shares were listed in the London Gazette in July 1817, there were 29 canals, 3 docks, 9 bridge/road, 7 water, 1 gas, 10 insurance and only 8 that could be considered commercial, including 3 mines. In other words, the stock exchange was dominated by domestic State debt and infrastructure. The companies busy delivering the industrial revolution were privately or family owned and did not need to raise capital on the stock market. The capital markets were delivering the infrastructure for industry and trade to run on. Finance slowly shifted from a negative feedback loop of converting savings into the destructive intent of war into the positive feedback loop of re-investing profits and savings into infrastructure that lowered the costs of transport, increased the size of markets, made information flows faster, and increased overall welfare and quality of life. "Instead of borrowing for 
unproductive military purposes, governments were bequeathing to later generations ownership of profitable assets like railways, docks and public utilities and contributing to the means of paying these debts through rising national incomes" (Michie 2006, 86).

This shift in capital market structure is illustrated in Figure 7. In 1853, over $70 \%$ of the value of securities on the London Stock Exchange (LSE) was domestic public sector debt, $20 \%$ was infrastructure stocks and shares, mainly in railways plus a small amount in canals and water supply. By 1913, domestic debt was down to $12 \%$ and dwarfed by foreign securities. Domestic and foreign railways alone represented almost $40 \%$ of the total value of all securities. By 1913, the old infrastructures of canals and water supplies had all but disappeared to be replaced by the new industries of energy, telecoms and tramways. As markets and company cash flows matured, bonds replaced equity as the financial instrument of choice for raising new funds. After WWI, domestic public sector debt rose again due to war bonds and a flight from overseas capital markets.

\section{Composition of London Stock Exchange Listed Securities (end of year quoted value)}

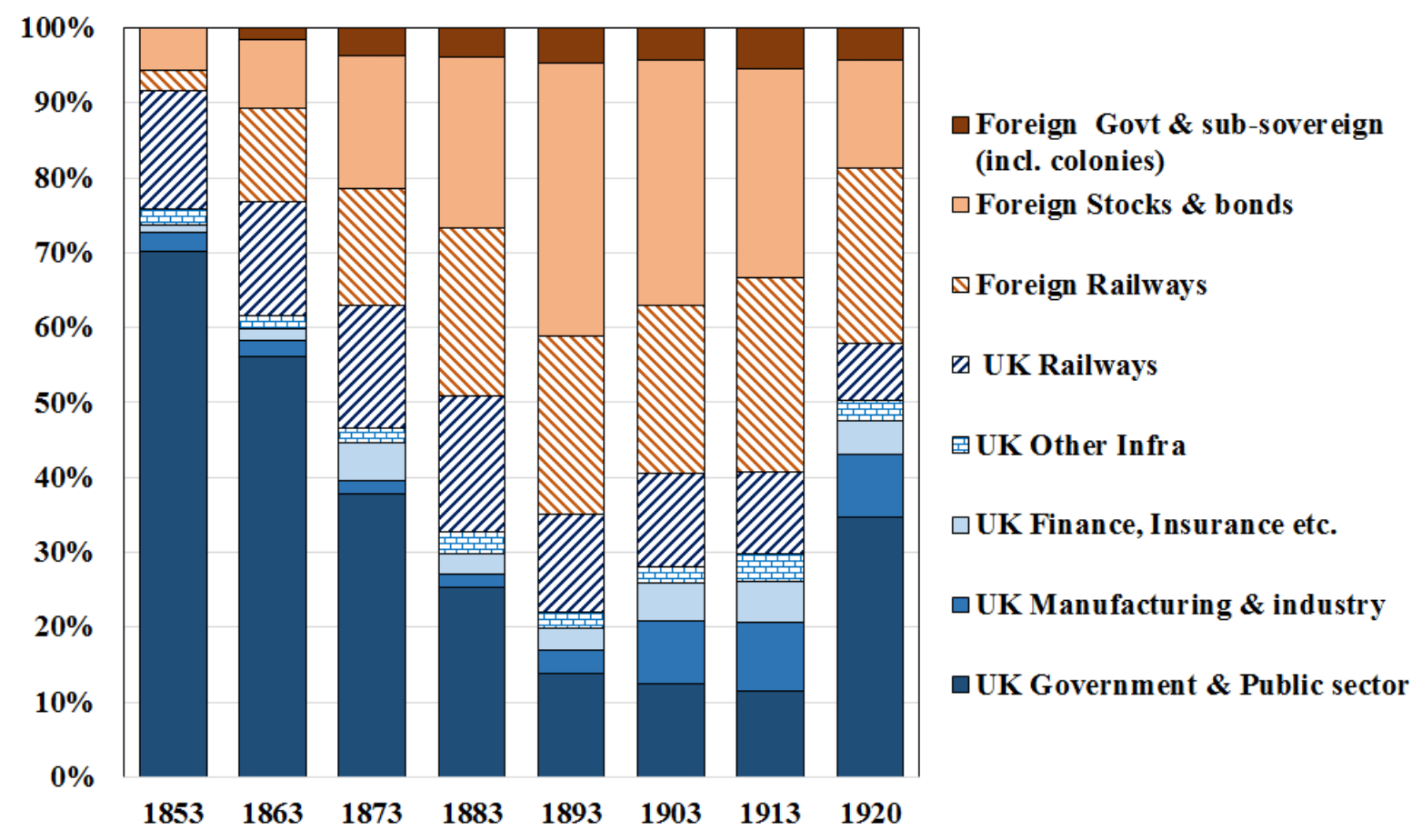

Figure 7. The changing structure of UK stock market investments 1853 to 1920

Source: Percentages derived from Table 5 in Goetzmann and Ukhov (2006) based on original data in Morgan and Thomas (1962).

\section{Conclusions}

The physical infrastructure systems that underpin everyday life in a modern economy have evolved over hundreds and sometimes thousands of years. The basic elements of urban, water, sanitation, transportation and communication systems were well developed by the late Roman Empire. This required not only the engineering knowledge to build large scale public works, but also the institutions to operate, contract and provide a legal framework for critical matters like using public 
rights of way, charging for services and enforcing contracts. After a pause of several centuries, a new generation of private infrastructure projects started in Britain after 1500 with an acceleration in the early 1800s that has sustained two centuries of unparalleled increase in wealth and well-being. Infrastructure was at the core, not the periphery of this story.

Throughout history, the pivotal role of the State as regulator, contracting authority and default investor in public infrastructure is self-evident. In contrast, the involvement of the private sector has waxed and waned over millennia, although at times it has been pivotal in bringing innovation, taking risks and driving efficiency. Evaluating the merits of different theoretical frameworks in explaining such long run dynamics, only a multi-disciplinary, systems approach that embraces innovations in technology, finance and institutions can capture the positive feedback between capital markets and investments in infrastructure that lower system-wide transaction costs for industry, households and governments alike.

Innovation does not stop with the big bang moment of inventing the railways or electricity. It goes on through competition between rival systems to establish a standard for the new technology, through finding new organizational and financing models to deliver rapid expansion, through regulation or social ownership to ensure that benefits are extended to all through universal service. It requires incentives through competition or regulation to keep grinding out the efficiency gains that deliver improvements to quality at lower costs. Infrastructure needs to be central to the development of a "national system of innovation".

Does history have anything useful to tell us about our current infrastructure challenges? Perhaps. Spotting the historic parallels and understanding how particular projects and policies played out in the past will surely help us make better decisions today. Of course, the context will always be different. The art is to appreciate the differences as well as the similarities and use them to enrich our understanding of the risks and opportunities we face.

Just as Vitruvius lamented that the Romans had forgotten Greek contracting practices, with a better grasp of history, there are rich seams of knowledge to be re-explored. "New" approaches to infrastructure finance using land grants or performance-based subsidy competitions between firms to complete different components of a network were all successful experiments in the past that researchers and practitioners could fruitfully examine for inspiration.

Meanwhile, the next techno-economic paradigm may already be with us in the form of "sustainability" and all that it implies for renewables, green infrastructure and decoupling growth from wasteful exploitation of resources. In any case, infrastructure needs to be understood as more than an input into a growth optimization game: it literally underpins civilized life. 


\section{References}

Abbate, Janet. 2000. Inventing the internet. MIT press.

Adams, Robert McC. 2010. "Slavery and Freedom in the Third Dynasty of Ur: Implications of the Garshana Archives." Cuneiform Digital Library Journal: 2.

http://www.cdli.ucla.edu/pubs/cdlj/2010/cdlj2010_002.pdf (accessed October 4, 2014)

Agénor, Pierre-Richard. 2007. "Fiscal policy and endogenous growth with public infrastructure." Oxford Economic Papers.

Albert, William. 2007. The Turnpike Road System in England: 1663-1840. Cambridge University Press.

Aschauer, David Alan. 1989. "Is public expenditure productive?" Journal of monetary economics 23, no. 2: 177-200.

Bagg, Ariel M. 2012. "Irrigation." in Potts, Daniel T., ed. A Companion to the Archaeology of the Ancient Near East. John Wiley \& Sons: 261-278.

Barro, Robert J. 1990. "Government Spending in a Simple Model of Endogenous Growth." Journal of Political Economy 98, no. 5 pt 2.

Bel, Germà. 2011. "The first privatisation: selling SOEs and privatising public monopolies in Fascist Italy (1922-1925)." Cambridge journal of economics 35, no. 5 (2011): 937-956.

Bezançon, Xavier. 2004. 2000 ans d'histoire du partenariat public-privé: pour la réalisation des équipements et services collectifs. Presses de l'École nationale des Ponts et chaussées.

Bogart, Dan. 2012. "The Transport Revolution in Industrializing Britain: A Survey." Working Paper. Department of Economics UC Irvine. http://www.socsci.uci.edu/ dbogart/transport_revolution_surveyjan2013.pdf (accessed October 4, 2014)

Bonin, Hubert. 2010. History of the Suez Canal Company, 1858-1960. Between Controversy and Utility. Droz, Genève.

Cadot, Olivier, Lars-Hendrik Röller, and Andreas Stephan. 2006. "Contribution to productivity or pork barrel? The two faces of infrastructure investment." Journal of Public Economics 90, no. 6: 1133-1153.

Campbell, Gareth, and John David Turner. 2010. 'The Greatest Bubble in History': Stock Prices during the British Railway Mania. MPRA Paper No. 21820. University Library of Munich, Germany, http://mpra.ub.uni-muenchen.de/21820/ (accessed November 27, 2013)

Casson, Mark. 2009. The world's first railway system: enterprise, competition, and regulation on the railway network in Victorian Britain. Oxford University Press.

Chandler, Tertius. 1987. Four thousand years of urban growth: an historical census. St. David's University Press.

Charlesworth, George. 1984. A history of British motorways. Thomas Telford Ltd.

Corble, Nick. 2011. James Brindley: the first canal builder. Faber \& Faber.

Croce, Raffaele Della. 2011. Pension funds investment in infrastructure: policy actions. No. 13. OECD Publishing.

De Luca, Giuseppe, and Marcella Lorenzini. 2913. "A taxonomy of infrastructure financing in Europe on the long run (12th-18th century)." Entreprises et histoire 1: 10-36.

Diamond, Jared. 2005. Collapse: how societies choose to fail or succeed. Penguin.

Dissou, Yazid, and Selma Didic. 2013. "Infrastructure and Growth." in John Cockburn et al. eds., Infrastructure and Economic Growth in Asia. Springer Open International Publishing: 5-45.

Eck, Werner. 2007. The age of Augustus. John Wiley and Sons Ltd.

Égert, Balázs and Kozluk, Tomasz J. and Sutherland, Douglas, 2009. Infrastructure and Growth: Empirical Evidence. OECD Economics Department Working Paper No. 685. http://ssrn.com/abstract=1360784 (accessed November 27, 2013) 
Eichengreen, Barry. 1995. "Financing infrastructure in developing countries: lessons from the railway age." The World Bank Research Observer, 10(1): 75-91.

Esfahani, Hadi Salehi, and María Teresa Ramírez. 2003. "Institutions, infrastructure, and economic growth." Journal of Development Economics 70, no. 2: 443-477.

Estache, Antonio. 2004. Emerging infrastructure policy issues in developing countries: a survey of the recent economic literature. Vol. 3442. World Bank Publications.

Feis, Herbert. 1930. Europe: The World's Banker, 1870-1914. Yale University Press.

Flyvbjerg, Bent, Nils Bruzelius, and Werner Rothengatter. 2003. Megaprojects and risk: An anatomy of ambition. Cambridge University Press.

Foreman-Peck, James, and Robert Millward. 1994. Public and private ownership of British industry, 1820-1990. Oxford: Clarendon Press.

Fouquet, Roger. 2008. Heat, power and light: revolutions in energy services. Edward Elgar Publishing.

Freeman, Christopher. 1992. The Economics of Hope. Essays on Technical Change, Economic Growth and the Environment. Pinter, London.

Freeman, Chris, and Francisco Louçã. 2001. As Time Goes By: From the Industrial Revolutions to the Information Revolution. Oxford University Press.

Friedlander, Amy. 1995a. Emerging infrastructure: the growth of railroads. History of Infrastructure Series (Vol. 1). Corporation for National Research Initiatives.

Friedlander, Amy. 1995b. Natural monopoly and universal service: Telephones and telegraphs in the US communications infrastructure, 1837-1940. History of Infrastructure Series (Vol. 2). Corporation for National Research Initiatives.

Friedlander, Amy. 1996. Power and Light: Electricity in the US Energy Infrastructure, 1870-1940. History of Infrastructure Series (Vol. 3). Corporation for National Research Initiatives.

Friedlander, Amy. 2005. Communications and Content: Radio technologies in the US infrastructure 1865-1976. History of Infrastructure Series (Vol. 5). Corporation for National Research Initiatives.

Garbrecht, Günther. 1980. "The water supply system at Tuşpa (Urartu)." World Archaeology 11, no. 3 (1980): 306-312.

Geels, Frank W. 2004. "Understanding system innovations: a critical literature review and a conceptual synthesis." in Elzen, Boelie, Frank W. Geels, and Kenneth Green, eds. System innovation and the transition to sustainability: theory, evidence and policy. Edward Elgar Publishing: 19-47.

Goblot, Henri. 1979. Les qanats: une technique d'acquisition de l'eau. Vol. 9. Editions de l'Ecole des Hautes Etudes en Sciences Sociales.

Goetzmann, William N., and Andrey D. Ukhov. 2006. "British investment overseas 18701913: a modern portfolio theory approach." Review of Finance 10, no. 2: 261-300.

Golden, Miriam A., and Lucio Picci. 2008. "Pork-Barrel Politics in Postwar Italy, 1953-94." American Journal of Political Science 52, no. 2: 268-289.

Goldsmith, Hugh. Forthcoming. "Financing the evolution of London's water services: 1582 to 1904 ".

Gómez-Ibáñez, José A. 2009. Regulating infrastructure: monopoly, contracts, and discretion. Harvard University Press.

Gramlich, Edward M. 1994. "Infrastructure Investment: A Review Essay." Journal of Economic Literature 32, no. 3: 1176-96.

Griffin, Jasper. 1986. "Introduction” to Boardman, John, Jasper Griffin, and Oswyn Murray, eds., The Oxford history of the classical world. Oxford University Press.

Grübler, Arnulf. 1990. The rise and fall of infrastructures: dynamics of evolution and technological change in transport. Physica-Verlag Heidelberg, Germany.

Grübler, Arnulf. 2003. Technology and global change. Cambridge University Press. 
Hansman, R. John, Christopher Magee, Richard De Neufville, and Renee Robins. 2006. "Research agenda for an integrated approach to infrastructure planning, design and management." International journal of critical infrastructures, 2(2): 146-159.

Hausman, William J., Peter Hertner, and Mira Wilkins. 2008. Global electrification: multinational enterprise and international finance in the history of light and power, 18782007. Cambridge Studies in the Emergence of Global Enterprise. Cambridge University Press.

Hughes, Thomas P. 1983. Networks of power: electrification in Western society, 1880-1930. Johns Hopkins University Press.

Jacobson, Charles David, and Joel Arthur Tarr. 1995. "Ownership and financing of infrastructure: historical perspectives." World Bank Policy Research Working Paper No. 1466. World Bank Publications.

Jansen, Michael. 1993. Mohenjo-daro: City of Wells and Drains, Water Splendour 4500 Years Ago. Frontinus Society Publications.

Knoepfler, Denis. 2001. “Le contrat d'Eretrie en Eubée pour le drainage de l'étang de Ptéchai." in Briant, Pierre, ed., Irrigation et drainage dans I'Antiquité. Qanats et canalisations souterraines en Iran, en Égypte et en Grèce. Thotm éditions: 41-79.

Koutsoyiannis, Demetris and Andreas N. Angelakis. 2003. "Hydrologic and Hydraulic Science and Technology in Ancient Greece" in Stewart, Bobby Alton, and Terry A. Howell. Encyclopedia of water science. Marcel Dekker Inc.

Lightfoot, Dale R. 2000. "The origin and diffusion of qanats in Arabia: new evidence from the northern and southern peninsula." The Geographical Journal 166, no. 3: 215-226.

López, Alberte Martínez. 2003. "Belgian investment in tramways and light railways: an international approach, 1892-1935." The Journal of Transport History 24, no. 1: 59-77.

Maddison, Angus. 2007. The world economy. Volume 1: A millennial perspective. Volume 2: Historical statistics. Academic Foundation.

Magnusson, Roberta J. 2003. Water technology in the Middle Ages: cities, monasteries, and waterworks after the Roman Empire. JHU Press.

Michie, Ranald. 2006. The global securities market: a history. Oxford University Press.

Millward, Robert. 2005. Private and public enterprise in Europe: energy, telecommunications and transport, 1830-1990. Cambridge University Press.

Mitchell, Brian R. 1992. International historical statistics: Europe 1750-1988. Stockton Press.

Mithen, Steven. 2012. Thirst: For Water and Power in the Ancient World. Harvard University Press.

Morgan, Edward Victor, and William Arthur Thomas. 1962. The stock exchange. Elek Books.

Morris, Ian. 2010. Why the west rules-for now: The patterns of history, and what they reveal about the future. Farrar, Straus and Giroux.

Nelson, Richard R., and Sidney G. Winter. 1982. An evolutionary theory of economic change. Harvard University Press,

Nelson, Richard R. 2008. "What enables rapid economic progress: What are the needed institutions?" Research Policy, 37(1), 1-11.

Newbery, David M. 2002. Privatization, restructuring, and regulation of network utilities. Vol. 2. MIT Press.

North, Douglass C. 1990. Institutions, institutional change and economic performance. Cambridge University Press.

North, Douglass C., and John J. Wallis. 1994. "Integrating Institutional Change and Technical Change in Economic History: A Transaction Cost Approach", Journal of Institutional and Theoretical Economics, 150 (4), pp. 609-624. 
North, Douglas C. 2006. Understanding the process of economic change. Academic Foundation.

Parker, David. 2012. The official history of privatisation. Vol. 2. Routledge.

Pawson, Eric. (1977). Transport and economy: the turnpike roads of eighteenth century Britain. Academic Press.

Perez, Carlota. 2002. Technological revolutions and financial capital: the dynamics of bubbles and golden ages. Edward Elgar.

Perez, Carlota. 2010. The financial crisis and the future of innovation: A view of technical change with the aid of history. No. 28. TUT Ragnar Nurkse School of Innovation and Governance.

Pirenne, Henri. 1956. Medieval cities: Their origins and the revival of trade. Vol. 82. Princeton University Press.

Prud'Homme, Rémy. 2005. "Infrastructure and Development." in Bourguignon, François and Boris Pleskovic, eds. Lessons of Experience (Proceedings of the 2004 Annual Bank Conference on Development Economics). The World Bank and Oxford University Press: 153-181.

Ragazzi, Giorgio, and Werner Rothengatter, eds. 2005. Procurement and financing of motorways in Europe. Vol. 15. Elsevier.

Reed, Malcolm C. 1975. Investment in Railways in Britain, 1820-1844: A study in the development of the capital market. Oxford University Press.

Rogers, Everett M. 1962. Diffusion of innovations. Free Press of Glencoe, New York.

Rohatyn, Felix G. 2009. Bold endeavors: How our government built America, and why it must rebuild now. Simon and Schuster.

Romp, Ward E., and Jakob De Haan. 2005. "Public capital and economic growth: a critical survey." EIB papers 10, no. 1: 41-70.

Schmidt, Klaus. 2000. "Göbekli Tepe, southeastern Turkey: A preliminary report on the 1995-1999 excavations”. Paléorient: 45-54.

Sitwell, Nigel H. 1981. Roman roads of Europe. Cassell.

Straub, Stephane. 2008. "Infrastructure and development: A critical appraisal of the macro level literature". World Bank Policy Research Working Paper Series Vol 4590. World Bank.

Temin, Peter. 2006. "The economy of the early Roman Empire." The Journal of Economic Perspectives. 20(1): 133-151.

Toutain, Jules. 1930. The economic life of the ancient world. London: Kegan Paul, Trench, Trubner \& Co. Ltd.

Trew, Alex. 2010. "Infrastructure Finance and Industrial Takeoff in England." Journal of Money, Credit and Banking 42, no. 6: 985-1010.

Vitruvius Pollio. 1914. Vitruvius Pollio, The Ten Books on Architecture. Morris Hicky Morgan, ed. Harvard University Press. https://archive.org/details/cu31924005226513 (accessed November 27, 2013)

Ward, Robert. 2003. London's New River. Phillimore Company Limited.

Wittfogel, Karl A. 1957. Oriental despotism; a comparative study of total power. Yale University Press. 